\title{
1. LEG 121 BACKGROUND AND OBJECTIVES ${ }^{1}$
}

\author{
Shipboard Scientific Party ${ }^{2}$
}

\section{TECTONIC SETTING}

The tectonic histories of the Kerguelen-Heard Plateau, Broken Ridge, and Ninetyeast Ridge (Figs. 1 and 2) are derived from the history of the Kerguelen/Ninetyeast hot spot in the context of the evolution of the Indian Ocean (Sclater and Fisher, 1974; Schlich, 1982; Patriat, 1983; Patriat and Achache, 1984). A summary discussion of the tectonic history of the eastern Indian Ocean is included in the "Ninetyeast Ridge Summary" chapter (this volume). Maps of plate reconstructions at times that are important for the sites drilled on Leg 121 are in the Appendix to this chapter.

Broken Ridge and the Kerguelen-Heard Plateau are conjugate rifted fragments of an oceanic platform (Fig. 3) that probably formed from intraplate volcanism in Early Cretaceous or mid-Cretaceous time (e.g., Morgan, 1981). The basement rocks of both features are basaltic, based on the recovery to date from limited dredging (Leclaire et al., 1987; Robert D. Conrad Cruise 2708, unpubl. data) and the drilling results of Ocean Drilling Program (ODP) Legs 119 (Barron, Larsen, et al., 1989) and 120 (Schlich, Wise, et al., 1989). Ninetyeast Ridge is interpreted to be a hot-spot trace of mid-Cretaceous to Oligocene age produced when the Kerguelen hot spot was either under the Indian plate or at the Indian/Antarctic spreading center (Luyendyk, 1977; Luyendyk and Rennick, 1977). Basement rocks recovered from Ninetyeast Ridge on Deep Sea Drilling Project (DSDP) Legs 22 (von der Borch, Sclater, et al., 1974) and 26 (Davies, Luyendyk, et al., 1974) are basaltic with geochemical affinities with Kerguelen (Frey et al., 1977; Mahoney et al., 1983; Weis et al., 1987). In addition, the increasing age to the north (Duncan, 1978 ) and the paleolatitudes of the basalts near $50^{\circ} \mathrm{S}$ (Peirce, 1978 ) indicate a genetic relationship between Ninetyeast Ridge and the Kerguelen-Heard Plateau.

\section{BROKEN RIDGE}

The present-day separation of Broken Ridge and Kerguelen Plateau (the northern half of the Kerguelen-Heard Plateau) is due primarily to lithospheric extension (i.e., rifting) and secondarily, to seafloor spreading that began before anomaly 18 time ( 42 Ma; Berggren et al., 1985; Mutter and Cande, 1983) and has continued to the present day. Since the middle Eocene, Broken Ridge has moved north by about $20^{\circ}$ of latitude as part of the Indo-Australian plate, while the Kerguelen-Heard Plateau, as part of the Antarctic plate, has had little latitudinal movement.

Previous DSDP drilling at Broken Ridge (Site 255; Fig. 4) terminated at $108 \mathrm{~m}$ below seafloor (mbsf) in an outer shelf/upper slope limestone and chert sequence of Santonian age (Davies, Luyendyk, et al., 1974). The limestone with chert unit is unconformably overlain by about $20 \mathrm{~m}$ of middle to upper Eocene detrital sands and gravels deposited in shallow water. A 55-

\footnotetext{
${ }^{1}$ Peirce, J., Weissel, J., et al., 1989. Proc, ODP, Init. Repts., 121: College Station, TX (Ocean Drilling Program).

2 Shipboard Scientific Party is as given in the list of Participants preceding the contents.
}

m-thick Neogene pelagic cap disconformably overlies the upper Eocene sediments.

Broken Ridge is noteworthy because the effects of rifting are evident in its seismic stratigraphy (Figs, 4 and 5). Because Broken Ridge has remained a fairly shallow-water platform throughout its history, the stratigraphic section there could potentially provide a clear record of the vertical motions of Broken Ridge as it responded to the rifting process. In particular, riftrelated uplift exposed parts of Broken Ridge above sea level, and a distinctive angular unconformity cut across the pre-rift strata provided a detrital source for the middle to upper Eocene shallow-water sands and gravels found at Site 255 .

The seismic-reflection profile passing through the site locations (Fig. 5) delineates four seismic stratigraphic units that are discussed in detail elsewhere in this volume (see "Broken Ridge Underway Geophysics" chapter and the site chapters). Two of these units are clearly truncated by the erosional unconformity. Together they comprise a northward-dipping sedimentary sequence in which the upper, more highly stratified unit thins to the north and downlaps the older, underlying unit. Prior to drilling it was unknown whether all of the dipping, truncated sediments were deposited before rifting began (i.e., a pre-rift sequence) or whether the downlapping unit consists of material eroded from uplifted and exposed parts of Broken Ridge (i.e., a syn- and post-rift sequence). As discussed in the following, answering that question was an important drilling objective at Broken Ridge. The subhorizontal seismic sequence above the truncation surface (Fig. 5) is probably a post-rift sequence. According to Site 255 results, this capping unit probably consists of middle to upper Eocene detrital sands and gravels and Neogene oozes deposited at or after the start of seafloor spreading between Broken Ridge and the Kerguelen Plateau (anomaly 18 time, $\sim 42 \mathrm{Ma}$ ). The age and nature of the fourth seismic stratigraphic unit that onlaps the northern slope of Broken Ridge (Fig. 5) is unknown. This fourth unit is possibly the downslopetransported and reworked product of stratigraphically lower parts of the section that were uplifted above sea level during rifting and erosion. Because no drill sites were planned for coring the onlapping unit, its age and origin can only be inferred indirectly.

\section{Theoretical Models for Extension of the Lithosphere}

The stratigraphic section at Broken Ridge can be used to study the process of lithospheric extension by assuming that in the absence of a rifting event, Broken Ridge would have subsided from the mid-Cretaceous onward as a result only of lithospheric cooling with time (i.e., thermal contraction). The form of such subsidence is known from empirical studies of seafloor depth as a function of age (e.g., Parsons and Sclater, 1977) and from theoretical models for cooling of oceanic lithosphere away from the ridge crest (Davis and Lister, 1974; Parker and Oldenburgh, 1973). Sediments deposited on a cooling oceanic platform would simply provide a source of additional subsidence, and the depth of the plateau basement surface over time can be determined by accounting for the extra subsidence resulting from sedimentation. A rifting event, however, would disrupt the normal pattern of thermal subsidence because of mechanical and/ or thermal effects associated with lithospheric extension. Our 


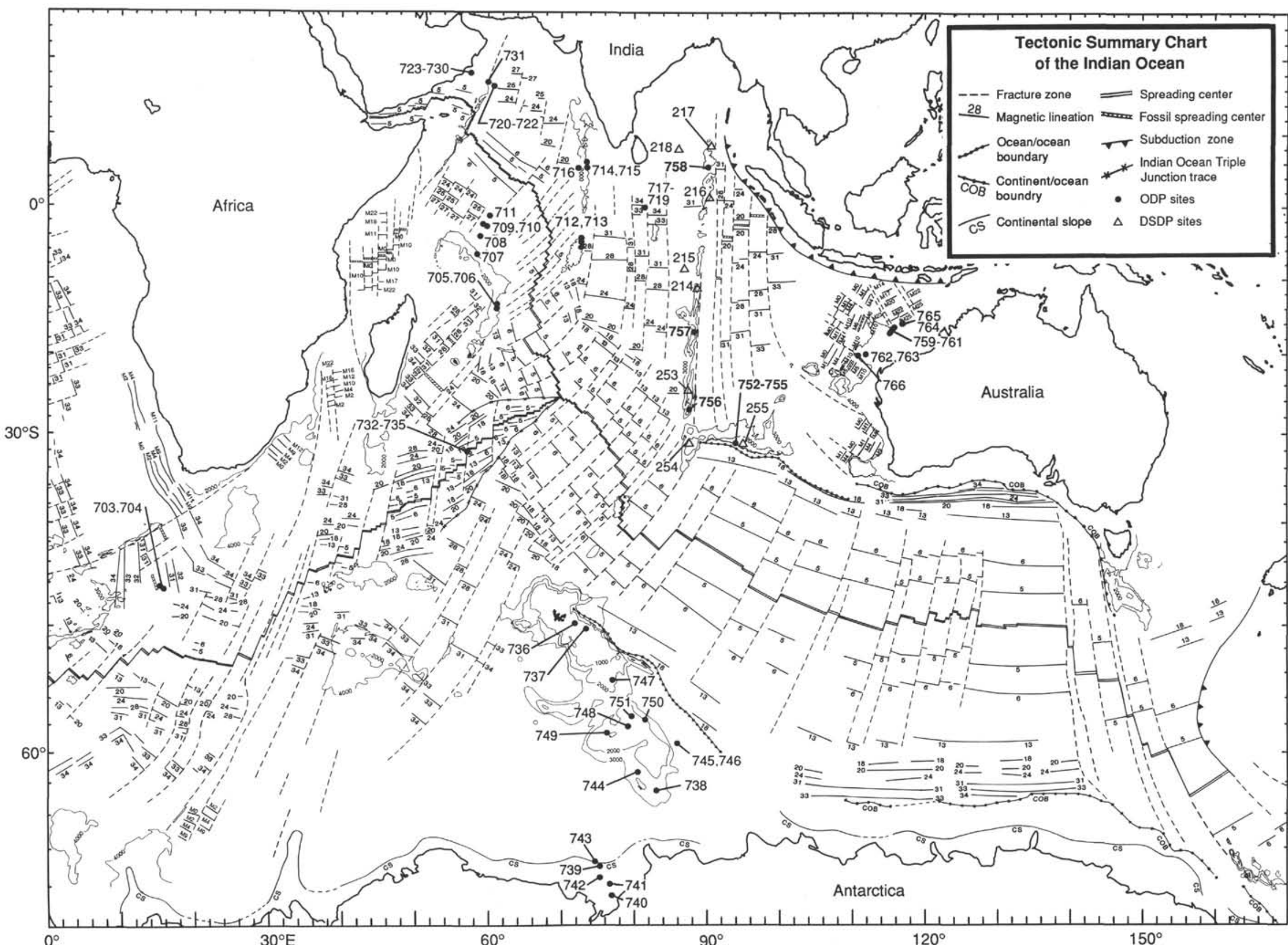

Figure 1. Index map of the Indian Ocean, showing major bathymetric plateaus and ridges, magnetic anomalies, and DSDP/ODP sites (after Royer et al., in press). 


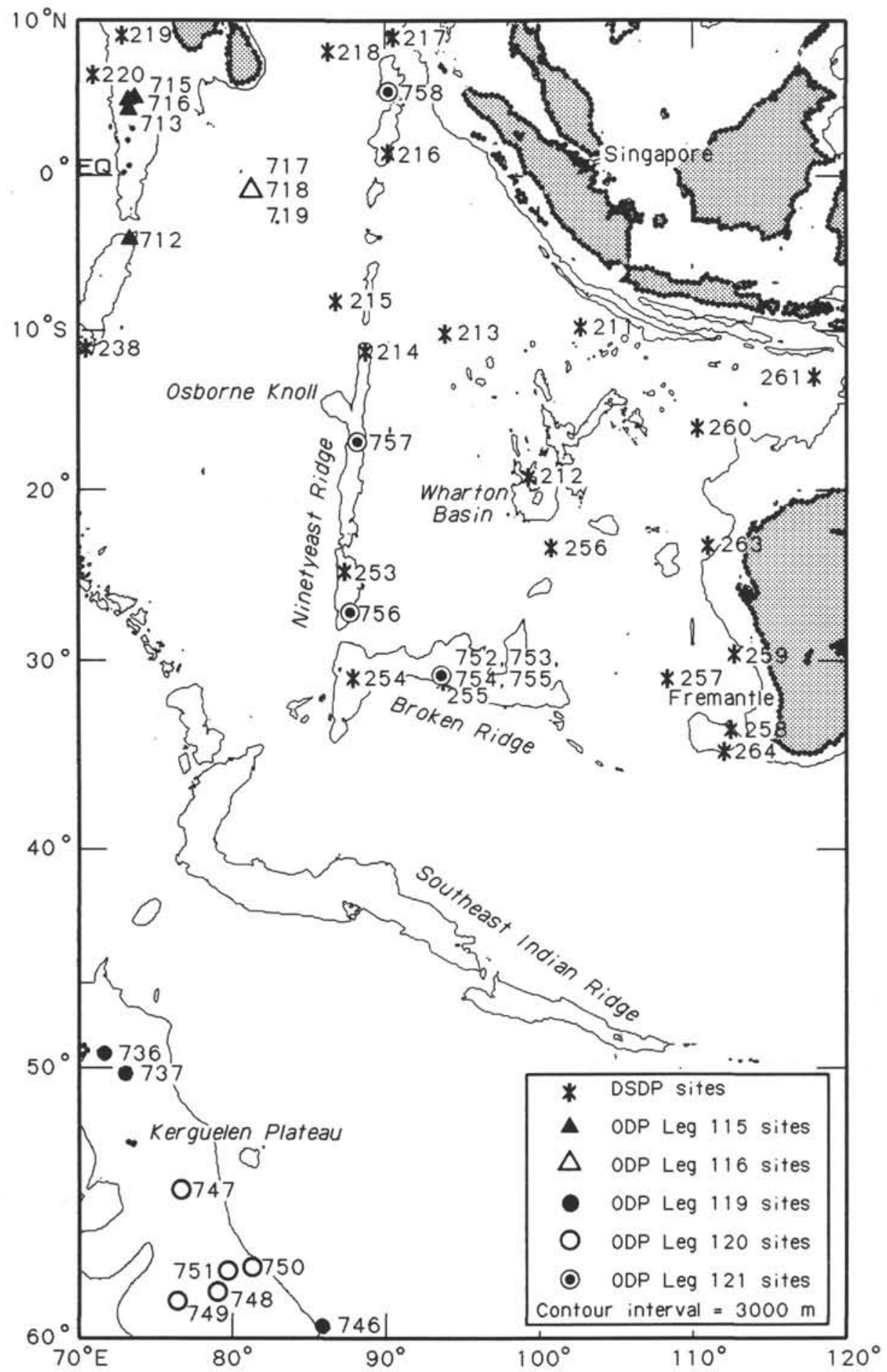

Figure 2. Location map of the eastern Indian Ocean showing DSDP and ODP sites.

overall aim for drilling at Broken Ridge is to extract rift-related information from the preserved sedimentary record to help us understand how the lithosphere responds to extension.

Two major problems concerning lithospheric extension addressed through drilling at Broken Ridge are (1) What is the role of the sublithospheric mantle in initiating lithospheric extension? and (2) What is the magnitude of vertical motion of the rift flanks during (and after) extension, and what is the implication of such vertical motions for the mechanical strength of extended lithosphere?
The first question concerns the nature and origin of the tectonic forces that "drive" extension. Two alternative views of the rifting process have been widely discussed in the literature (e.g., Sengor and Burke, 1978; Spohn and Schubert, 1982). These two views regard rifting as an "active" or a "passive" process, respectively. Active and passive here refer to the role of the asthenosphere (the hot upper mantle beneath the thermally defined lithosphere) in the rifting process. Active rifting is believed to be induced by convective upwelling in the asthenosphere, which thins the lithosphere from below and causes uplift by 


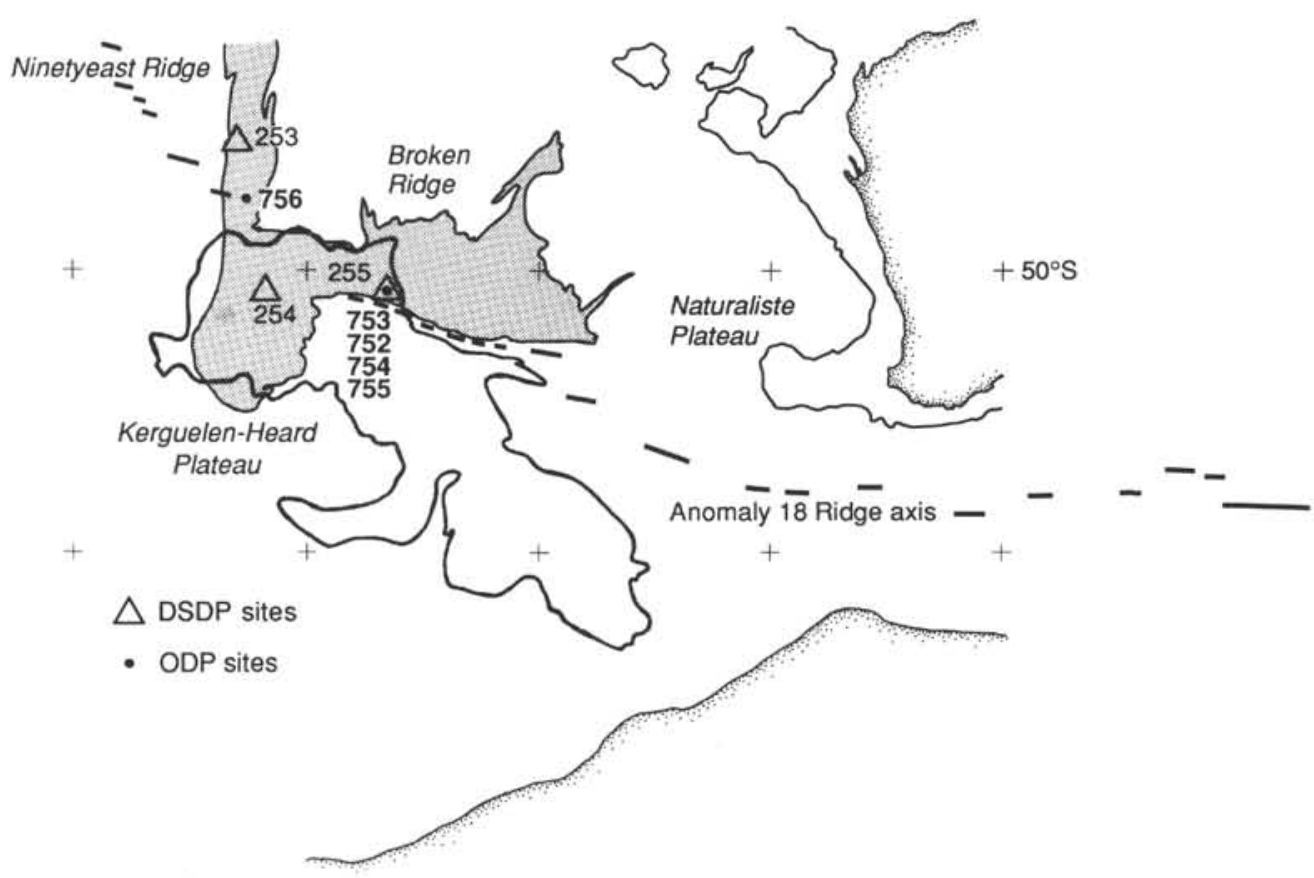

Figure 3. Paleogeographic reconstruction of Broken Ridge and the Kerguelen-Heard Plateau at the time of magnetic anomaly 18 ( $\sim 2 \mathrm{Ma})$. (Simplified from J.-Y. Royer, pers. comm., 1988). Broken Ridge and Ninetyeast Ridge are shaded. Overlap is due to volcanic construction after rifting, both at the southern end of Ninetyeast Ridge and at the northern end of the Kerguelen-Heard Plateau. Also see the Appendix of this chapter for reconstructions at other times.

thermal expansion. Tensile body forces resulting from uplift would then provide the forces necessary to extend (i.e., rift) the lithosphere, which is weakened by heat introduced from below. It has been suggested that active rifting follows a volcanism-uplift-rifting time sequence of tectonic events (Sengor and Burke, 1978). The best example of active rifting is in eastern Africa, where the eastern and western rift systems are superposed on a long-wavelength (1300-km-wide) topographic swell of about 1 $\mathrm{km}$ amplitude. In the oceans, a thermal swell of similar dimensions parallels the Hawaiian seamount chain, although rifting there is not significant (possibly because of the greater strength of old oceanic lithosphere relative to continental lithosphere). For an oceanic platform, such as Broken Ridge-Kerguelen Plateau, an active rifting process might be recorded in the sedimentary section as a reversal from a subsidence trend to gradual shoaling a few to several tens of million years before the actual rifting event.

Passive rifting, on the other hand, is believed to result from transmission of horizontal stress through the upper, mechanically strong part of the lithosphere. The source of this laterally varying, horizontal (in-plane) stress is attributed to the forces arising from the interaction of the lithospheric plates along their mutual boundaries. Under this idea, extension occurs at locations of low intrinsic lithospheric strength when the level of relative tensile stress is high enough. It has been suggested that passive rifting would follow a rifting-(volcanism)-uplift time sequence of tectonic events (Sengor and Burke, 1978). Similarly, the sedimentary section on an oceanic platform, such as Broken Ridge, might record this sequence of events. Perhaps the main distinguishing feature between the active and passive rifting hypotheses is the absence in passive rifting of a precursory uplift phase.

The second question focuses on the nature and implications of vertical motions of the lithosphere once rifting is initiated.
These vertical motions will occur regardless of whether extension is due to an active or a passive rifting process. The problem concerns isostasy, particularly in understanding the isostatic response of the lithosphere to the redistribution of mass and the perturbation of the lithospheric temperature structure that extension entails. The isostatic problem can be best understood by appealing to a simple forward-modeling procedure. In this procedure the isostatic problem is broken into two parts; the first involves the specification of a kinematic model for extension, and the second part involves the determination of the isostatic consequences of the kinematic model. The resulting topography across the extended region is the sum of the topography introduced in the kinematic model for extension and the topography required to balance isostatic restoring stresses engendered by extension (i.e., required to "regain" isostatic equilibrium). In the simplest models, extension is assumed to occur instantaneously, and the lithosphere is assumed to be in local isostatic equilibrium before extension. The results of modeling lithospheric extension are particularly sensitive to whether isostatic restoring forces, which arise when the lithosphere is kinematically perturbed, are assumed to be balanced in a local (or pointwise) or a regional (e.g., by lithospheric flexure) manner.

The critical question here is, Does extension reduce the strength of the lithosphere to zero (which implies local isostatic compensation) or is finite lithospheric strength maintained despite extensional deformation? This matter is controversial, but many are of the view that extended lithosphere has little or no strength (e.g., Barton and Wood, 1984; Fowler and McKenzie, in press; Watts, 1988), a condition attributed to mechanical causes (pervasive faulting in the upper part of the lithosphere) and to thermal causes (elevating the geotherm by extending and thinning the lithosphere).

However, Broken Ridge provides clear evidence that lithospheric strength is not completely destroyed when lithosphere is 
N
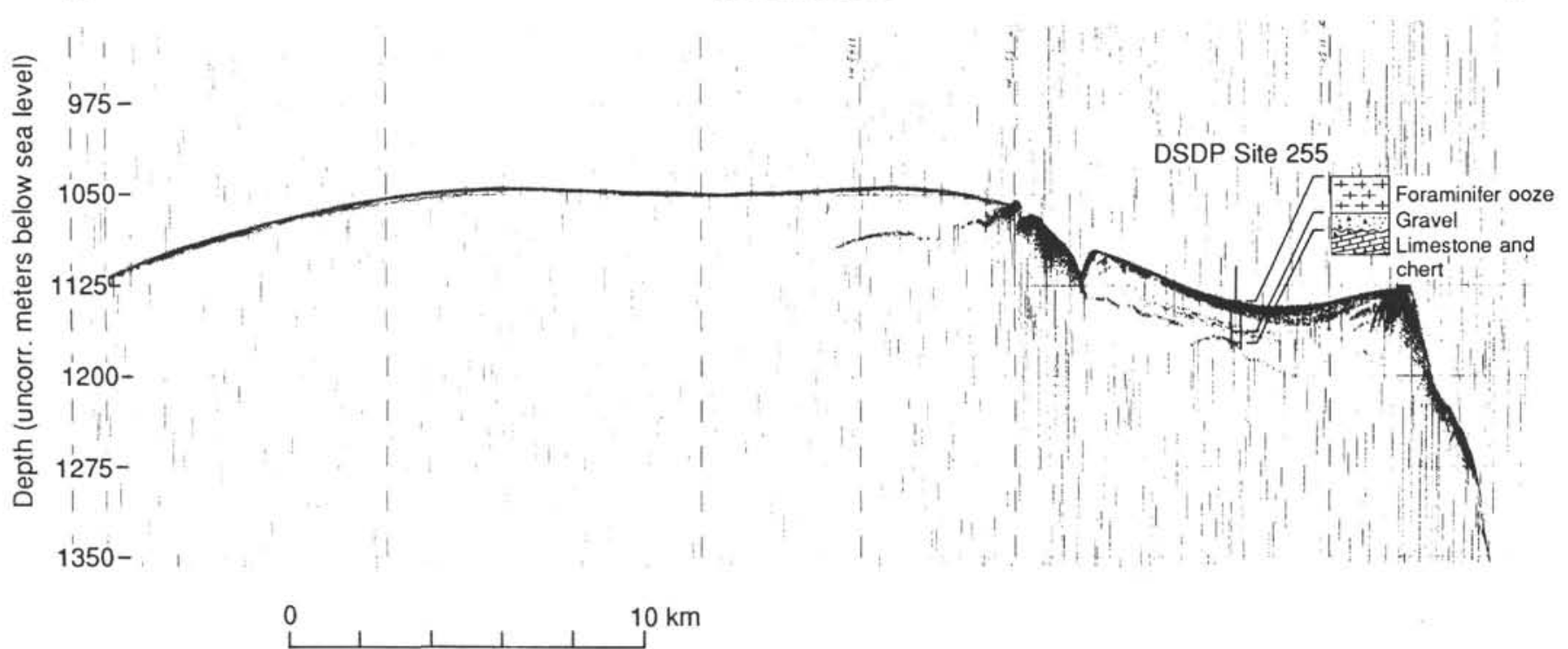

Figure 4. A 3.5-kHz echo-sounder profile across DSDP Site 255 obtained by Conrad Cruise 2708. Site 255 is on a small downdropped block to the south of the crest of Broken Ridge. The lithologies sampled at Site 255 are shown above the profile.

extended. First, the seismic stratigraphy (Fig. 5) suggests that Broken Ridge was uplifted and tilted to the north. By measuring the relief on the lower discontinuously reflective limestone and chert unit in the dipping and truncated sequence, we find that this unit was uplifted by a minimum of $1500 \mathrm{~m}$ at the crest of Broken Ridge relative to the same unit $50-100 \mathrm{~km}$ farther north. This uplift estimate is a minimum because some of the section was exposed above sea level and eroded, as indicated by the angular unconformity. Second, the relationship between the morphology of Broken Ridge and the associated gravity anomaly (see the following text and "Broken Ridge Underway Geophysics" and site chapters) suggests that the crust/mantle boundary is uplifted and tilted to the north in a manner similar to the seismic stratigraphic sequence below the unconformity (Weissel and Karner, in press).

These observations can be explained by the flexural uplift of Broken Ridge during extension by recognizing that the southward-dipping escarpment, which bounds Broken Ridge on the south, represents the bounding normal fault of the Broken RidgeKerguelen Plateau extensional system. West of about $94^{\circ} \mathrm{E}$ (i.e., in the vicinity of the Leg 121 drill sites), Broken Ridge is a rift shoulder on the footwall side of the rift system (see also "Broken Ridge Underway Geophysics" and site chapters). We can use a simple model for lithospheric extension to place these observations on a quantitative foundation.

Consideration of a simple model for rifting in which lithospheric extension is accommodated by instantaneous finite normal slip on an initially plane-inclined fault that cuts the entire lithosphere (Fig. 6) shows that uplift is the natural isostatic response to this simple kinematic model for extension. This crucial point becomes apparent when we consider that the kinematic perturbation described in Figure 6 produces a topographic "hole" that is immediately filled with air, water, or sediment (depending on the environment above the crust), all of which are less dense than the crustal rocks replaced. The deficit of pressure at a depth of compensation beneath the lithosphere gives the magnitude and distribution of normal stress (isostatic restoring stress) that must be balanced by uplift of the litho- sphere if isostatic equilibrium is to be regained. The critical point is that the strength of the lithosphere will determine how these isostatic restoring stresses are to be balanced. If the lithosphere has no strength, local isostatic compensation applies, and the uplift or subsidence at a particular location is linearly proportional to the isostatic restoring stress at that location only. However, if the strength of the lithosphere (as measured by its flexural rigidity) is not zero everywhere, the isostatic restoring stresses will be balanced regionally or, more simply, by the deflection of a thin elastic plate that is generally of variable elastic thickness $\left(\mathrm{T}_{\mathrm{e}}\right)$. The resulting topography across the extended region and its flanks is the sum of the topography introduced by the kinematic formulation for extension and the topography that balances the isostatic restoring stresses engendered by the kinematic model.

An example calculation is shown in Figure 7 to highlight the role played by the strength of the lithosphere in determining the topography resulting from extension. Four topographic profiles are shown, each one for a different value of effective elastic thickness, $T_{e}$, given in the lower-left box. The most important result from Figure 7 is that uplift of the footwall rift shoulder (the tectonic position of Broken Ridge during extension) cannot occur for a lithosphere with no strength $\left(\mathrm{T}_{e}=0\right.$ everywhere). As shown in Figure 8, we can closely match the morphology and gravity anomaly over Broken Ridge with the simple extensional model shown in Figures 6 and 7 if the "average" $T_{e}$ of Broken Ridge was $15-20 \mathrm{~km}$ at the time of rifting. $T_{e}$ values in that range are typical of $25-\mathrm{m}$.y.-old oceanic lithosphere (Bodine et al., 1981; Watts et al., 1980). The model topography in Figure 8 suggests that the original magnitude of flexural uplift at Broken Ridge was over $2000 \mathrm{~m}$, but the angular unconformity observed in the seismic stratigraphy (Fig. 5) indicates subsequent erosion of the "tip" of the uplifted rift shoulder.

The observed evidence (Figs. 5 and 7) and the simple modeling (Figs. 6 and 7) discussed in the preceding suggest that Broken Ridge was flexurally uplifted (by at least $1 \mathrm{~km}$ ) in response to extension. If true, this result is important because it runs counter to the popular opinion that maintains that extended 

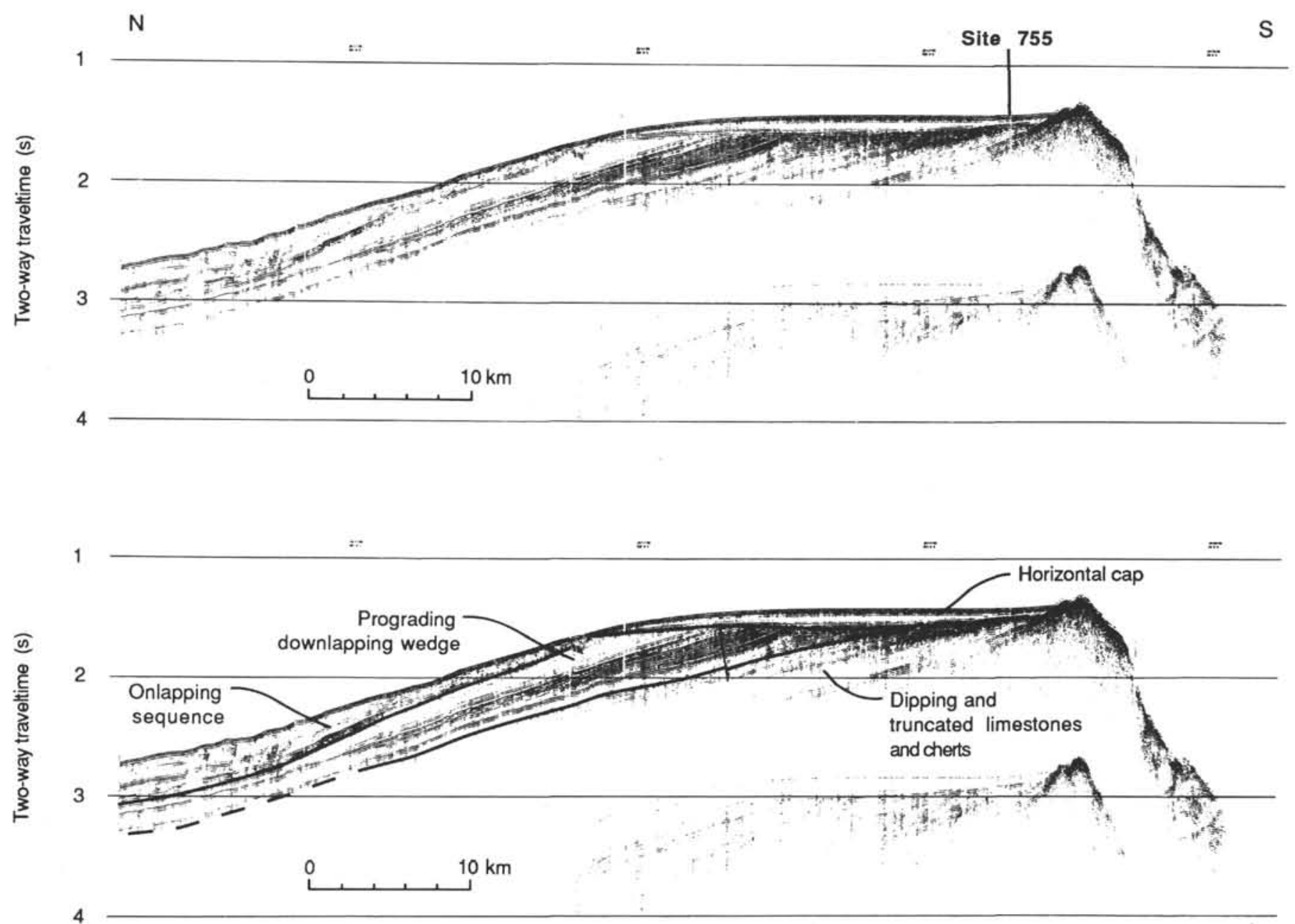

Figure 5. Single-channel seismic-reflection line 20 obtained during Conrad Cruise 2708. A prominent angular unconformity separates a thin, subhorizontal capping sequence above from northward-dipping reflector sequences below. The Leg 121 proposed drill sites are labeled on the upper diagram. The seismic stratigraphic sequences labeled on the lower diagram are discussed in detail in the "Broken Ridge Underway Geophysics" and site chapters.

lithosphere should have little or no strength. Drilling the sedimentary section of Broken Ridge on Leg 121 was meant to provide a definitive test of these ideas.

If rifting was of relatively short duration (a few million years), the following testable predictions can be made concerning the age and nature of the sedimentary section preserved today on Broken Ridge (Fig. 5):

1. The water depth at Broken Ridge before the onset of rifting was $\sim 1000 \mathrm{~m}$. Such a depth is necessary to provide the "headroom" required for the flexural uplift of Broken Ridge above sea level during extension and the cutting of the erosional unconformity.

2. Depositional environments should change across the erosional unconformity from open-ocean biogenic sedimentation before the rifting event to an interval, after extension, of shallow-water clastic sedimentation above the truncation surface.

3. Both the age of rift onset and the duration of rifting can be obtained by knowing the ages of the uppermost sediments below the unconformity and the basal sediments deposited on that surface. If our modeling assumptions are correct, the time gap across the unconformity should be small ( $<3$ m.y.).

These predictions apply strictly to a simple rifting event where all of the sediments in the dipping and truncated sedimentary sequence on Broken Ridge (Fig. 5) were deposited before rifting began and were originally subhorizontal. Seismic stratigraphic analysis, however, allows a second interpretation for this sequence (see "Broken Ridge Underway Geophysics" and site chapters). The upper, well-stratified unit in the dipping, truncated sequence thins northward and downlaps into the underlying unit. Because the upper well-stratified unit in the dipping, truncated sequence also onlaps the underlying unit, the interface between these units constitutes a seismic sequence boundary (Vail et al., 1980; Vail, 1984) that might denote the onset of rifting. If this is the case, the upper, well-stratified, downlapping unit would be interpreted as an upward-fining clastic unit composed of the detritus eroded from the flexurally uplifted crest of Broken Ridge following extension (i.e., a syn- and postrift sequence). Thus, the dipping and truncated sequence on 


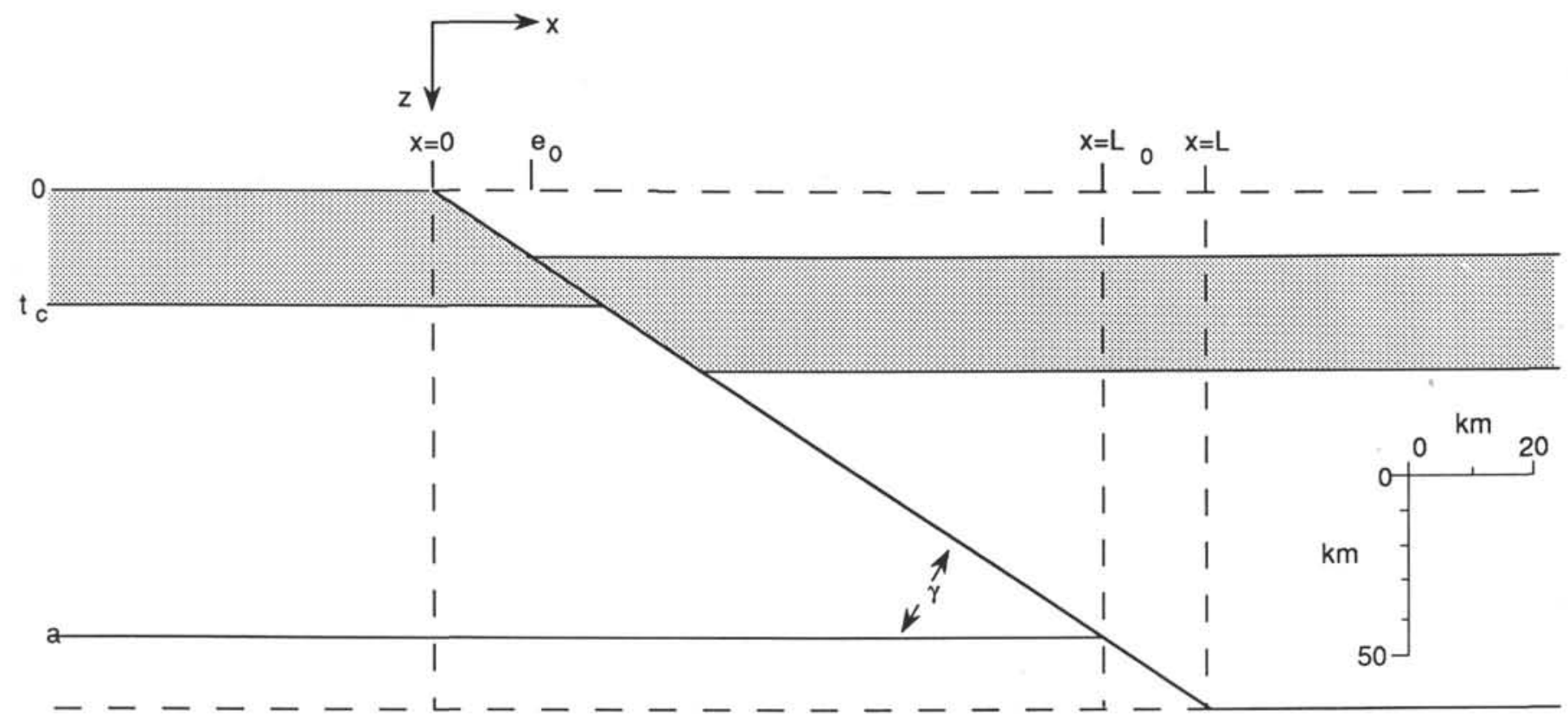

Figure 6. Simple kinematic model for extension of the lithosphere in which slip occurs instantaneosly on an initially plane, dipping normal fault that cuts the entire lithosphere (the crust is stippled); after Weissel and Karner (in press). The isostatic consequences of this kinematic model are discussed in the text. $\mathrm{e}_{\mathrm{o}}=\mathrm{amount}$ of extension; $\mathrm{t}_{\mathrm{c}}=$ crustal thickness; $\mathrm{a}=$ lithospheric thickness.

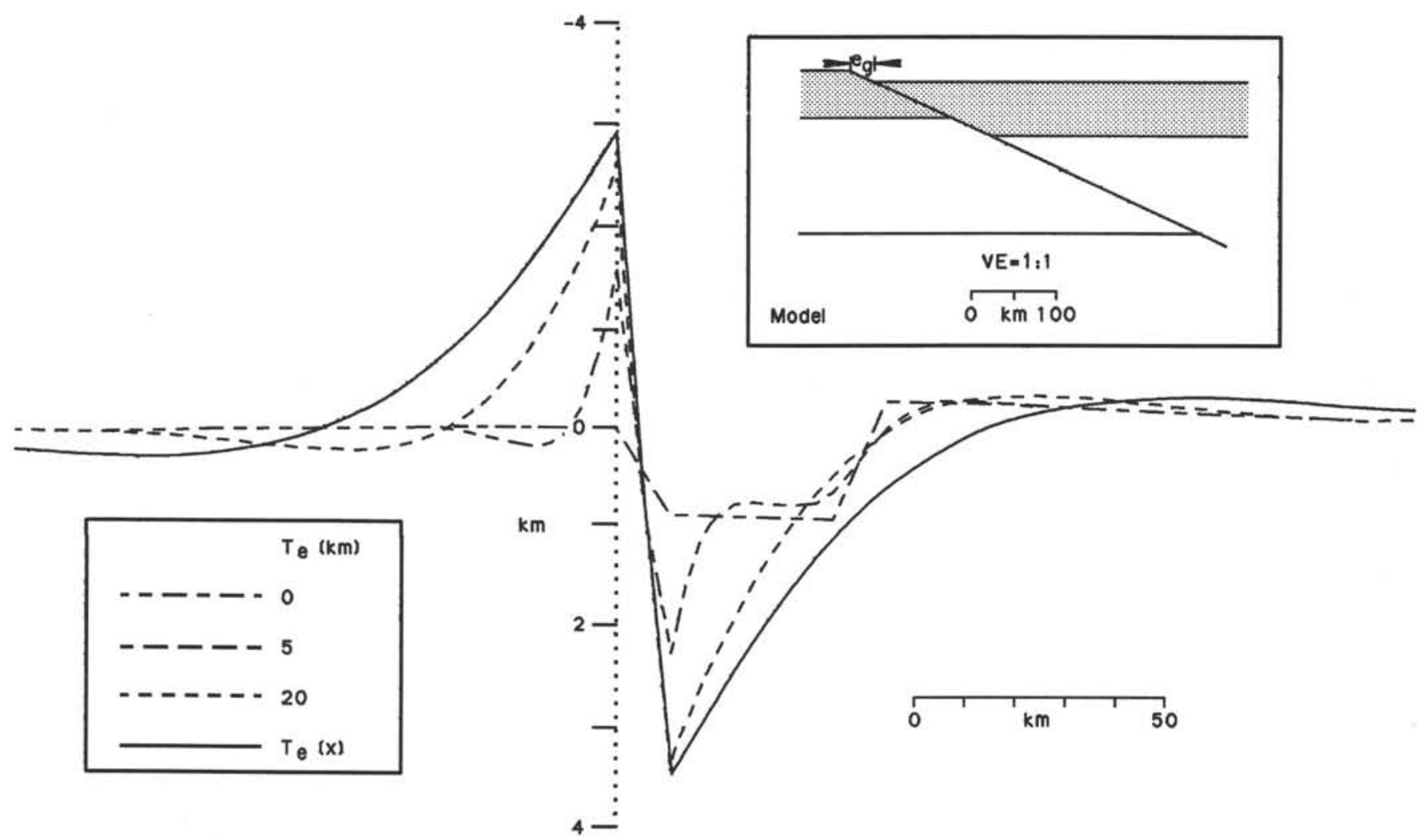

Figure 7. Topography resulting from the simple model for extension of the lithosphere via normal faulting (Fig. 6, inset upper right; from Weissel and Karner, in press). The topographic profiles were determined for the given values of effective elastic thickness $\left(T_{e}\right)$ for the lithosphere. The calculations pertain to the case in which air is the material above the lithosphere. For the profile with variable elastic thickness, $T_{e}(x)$, we assume that $T_{e}$ varies as the depth to a characteristic isotherm $\left(450^{\circ} \mathrm{C}\right)$ across the extended region. 


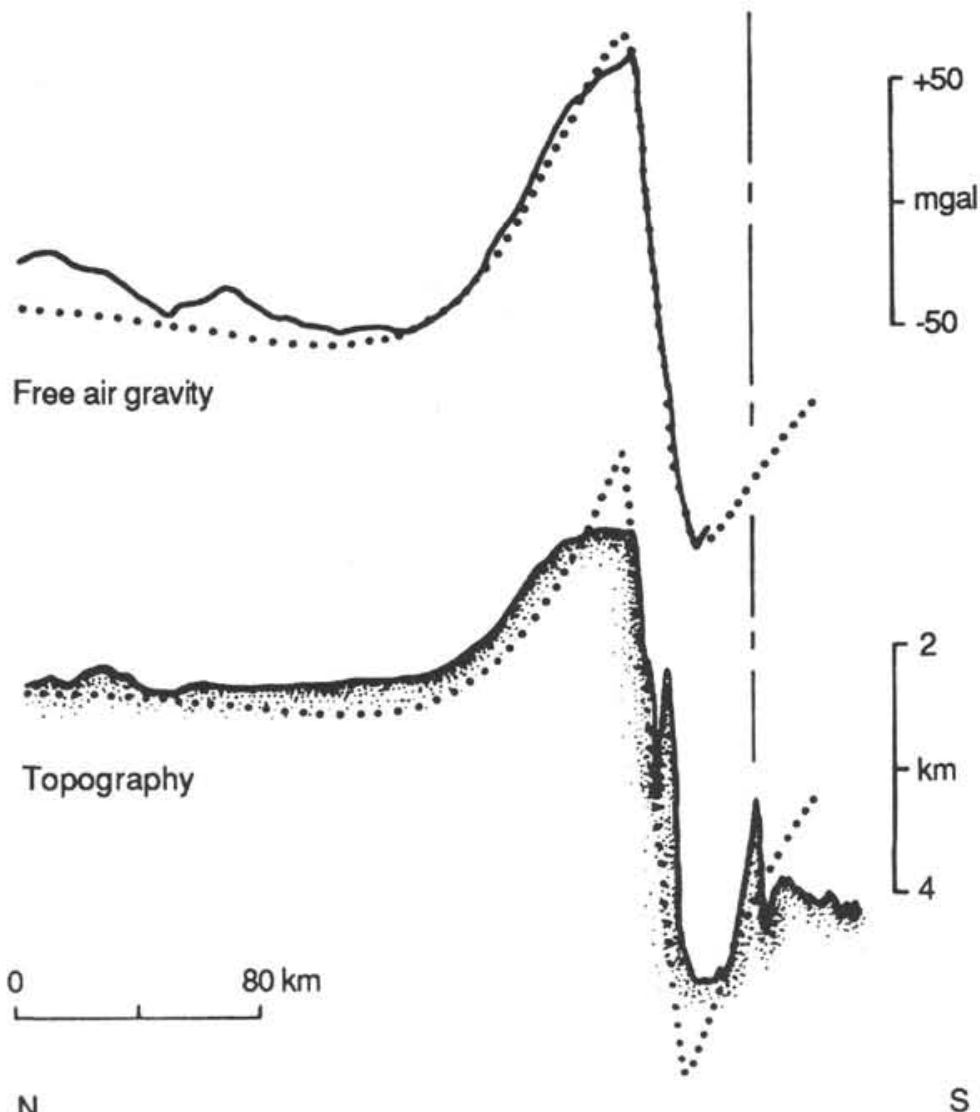

Figure 8. Comparison between observed morphology and gravity anomalies (solid lines) across Broken Ridge with best-fit models (dotted lines) obtained from the simple normal faulting extensional model shown in Figures 6 and 7 and discussed in the text (from Weissel and Karner, in press).

Broken Ridge would be regarded as including a pre-rift unit separated from a syn- to post-rift unit by the seismic sequence boundary. The age and nature of the observed truncation surface would change under this alternative interpretation of the seismic stratigraphy. That surface would represent a truncation event that occurred some time after rifting during a sea-level lowstand of sufficient magnitude to expose the crest of Broken Ridge to subaerial erosion a second time. It is unlikely that the original eroded surface of the pre-rift unit, which formed as a consequence of rifting, would survive a later erosional event. In this alternative sequence of tectonic events, the age of rifting would probably be Maestrichtian, similar in age to the uplift event affecting the central part of the Kerguelen Plateau found by drilling at Site 747 (Schlich, Wise, et al., 1989).

Although drilling can resolve which of the two interpretations for the dipping and truncated sequence is correct, the major drilling objective to be achieved at Broken Ridge was to demonstrate that rift flank uplift of about $2 \mathrm{~km}$ occurred in response to the rifting process. If this can be demonstrated, then we would conclude that the lithosphere maintains finite strength (or flexural rigidity) when it is extended.

\section{Objectives}

The foregoing discussion of theoretical models for extension of the lithosphere in relation to the observed seismic stratigraphy, gravity anomalies, and previous drilling (Site 255) at Broken Ridge allowed the formulation of the following drilling ob- jectives for the first part of ODP Leg 121. These objectives, which were designed to provide information on the response of the lithosphere to rifting processes, are as follows:

1. To ascertain the age, lithology, and depositional depth of the sediments in the dipping and truncated sedimentary sequence at Broken Ridge.

2. To ascertain the age, lithology, and depositional depth of the sediments comprising the subhorizontal sediments that cap the crest of Broken Ridge.

3. To determine, from these fundamental results, what parts of the total sedimentary section are pre-, syn-, and post-rift deposits.

4. To use the drilling results as constraints on the timing and duration of the rifting event and to determine the vertical motion of Broken Ridge as it responded to the rifting process.

For example, a prolonged precursory shoaling of the section at Broken Ridge before the actual rifting event would indicate that extension was initiated by an active process (i.e., convective mantle upwelling). However, a pre-rift section that was deepening prior to extension would suggest a passive rifting process (i.e., resulting from intraplate stress). If the upper part of the dipping and truncated sequence consists of open-ocean biogenic material deposited in water depths of $\sim 1000 \mathrm{~m}$, a middle Eocene rifting event of short duration $(\sim 5 \mathrm{~m}$.y. $)$ is the probable interpretation. On the other hand, if the downlapping unit in the 
dipping and truncated sequence is found to be composed of shallow-water clastics, a Maestrichtian rifting event would be favored.

\section{Drilling Strategy at Broken Ridge}

The objectives called for penetration and sampling of the entire dipping and truncated sedimentary sequence, which, on the basis of seismic-refraction velocities, is more than $1500 \mathrm{~m}$ thick (see "Broken Ridge Underway Geophysics" and site chapters). To do this at one site would have required setting a reentry cone, a time-consuming operation committing full effort to a single hole and lessening the contingency options. We employed an alternative drilling strategy in which the dipping and truncated sequence was sampled at a series of four single-bit holes (proposed Sites BR-1 through BR-4; Fig. 5). The drill sites were positioned to ensure overlap of the section between sites by taking advantage of the fact that progressively older strata subcrops beneath the unconformity as the main south-facing escarpment is approached (Fig. 5). Site 754 (proposed Site BR-3) was planned to penetrate the maximum thickness of the subhorizontally layered, post-rift sequence capping the crest of Broken Ridge (Fig. 5).

\section{NINETYEAST RIDGE}

The general drilling objectives on Ninetyeast Ridge were designed to study the geochemical relationships in space and time between the Ninetyeast Ridge and the Kerguelen hot spot; to derive a detailed northward-motion curve for the Indian plate, thereby providing further insight into the chronology and tectonic mechanisms of the Himalayan Orogeny; and to provide a south-north paleontological and paleoclimatologic transect of the eastern Indian Ocean at depths shallower than the carbonate compensation depth (CCD). These objectives complement the objectives of ODP Legs 115, 116, 117, 119, and 120 .

\section{Background}

Ninetyeast Ridge is a major north-south lineament in the eastern Indian Ocean. It extends from about $34^{\circ} \mathrm{S}$ to about $10^{\circ} \mathrm{N}$, a distance of almost $5000 \mathrm{~km}$, where it is buried by the sediments of the Bengal Fan (Fig. 2). The relief of Ninetyeast Ridge varies from 1500 to $3000 \mathrm{~m}$, and some peaks on its southern end shoal to $700 \mathrm{~m}$. Its width is about $200 \mathrm{~km}$, except for a 700 -km-long section north of Osborne Knoll, where it is as narrow as $100 \mathrm{~km}$. North of $8^{\circ} \mathrm{S}$, the morphology of the ridge is a series of en echelon blocks. The origin of this morphology is not understood.

Results from DSDP Legs 22 (von der Borch, Sclater, et al., 1974) and 26 (Davies, Luyendyk, et al., 1974) and other studies have shown that the basalts forming the basement of Ninetyeast Ridge erupted either subaerially or in shallow water. Basement ages increase northward along the ridge (Duncan, 1978, 1981) and are roughly the same as basement ages of the Indian plate to the west. The subsidence of the ridge with time follows the Parsons and Sclater (1977) age-depth curve for the oceanic crust, but with an offset to sea level at time zero (Detrick et al., 1977). The ridge is in local isostatic compensation (Bowin, 1973), which suggests that it formed on young, weak oceanic crust; this is in contrast to Hawaii, where the surrounding gravity anomalies and moat are evidence of volcanic loading on a relatively strong oceanic crust. Basement paleolatitudes are all near $50^{\circ} \mathrm{S}$ (Peirce, 1978), and the basalt geochemistry is similar to that of lavas from oceanic islands, particularly Kerguelen Island (Frey et al., 1977; Weis et al., 1987).
Ninetyeast Ridge is interpreted from these results to have formed as the trace of the Kerguelen/Ninetyeast hot spot on the Indian plate (Luyendyk, 1977; Luyendyk and Rennick, 1977) prior to rifting along the incipient Southeast Indian Ridge separated Kerguelen Plateau from the Indian plate in the middle Eocene (Chron 18 of the geomagnetic reversal time scale). The interpretation of the origin and structure of the Ninetyeast Ridge is complicated by a major left-lateral transform fault immediately east of the ridge. The history of the Ninetyeast Transform Fault is poorly understood, but in Late Cretaceous to Eocene time it is presumed to have connected the Indian-Antarctic Ridge to a then-active spreading center in the Wharton Basin. This plate boundary was active until Chron 19, when spreading in the Wharton Basin ceased and spreading on the Southeast Indian Ridge began (Luyendyk, 1977; Liu et al., 1983; Royer et al., in press).

It is not certain that India and Australia are, or ever were, part of the same plate. Stein and Okal (1978) reported earthquake focal mechanisms from a zone of seismicity between $10^{\circ} \mathrm{S}$ and $2^{\circ} \mathrm{N}$, and these indicate left-lateral strike-slip motion along the Ninetyeast Transform Fault. Several comprehensive kinematic plate models have resolved statistically significant relative motion between Australia and India (Minster and Jordan, 1978; Wiens et al., 1985; Molnar et al., 1988), and these earthquakes are often cited as evidence of present-day motion.

\section{Petrologic Objectives}

The principal petrologic objective of drilling on Ninetyeast Ridge is to obtain geochemical and petrological data from basement rocks in order to understand the origin of Ninetyeast Ridge and its relationship to the Kerguelen Plateau.

\section{Previous Drilling Results}

Sites 214 and 216 of DSDP Leg 22 and Sites 253 and 254 of Leg 26 recovered basaltic basement from Ninetyeast Ridge (Fig. 2 ). The following conclusions were reached from studies of these basalts:

1. The age of the basalts increases systematically from south to north (Duncan, 1978).

2. The trace element and radiogenic isotope characters of these Ninetyeast Ridge lavas are similar to those of oceanic island basalts and unlike Indian Ocean mid-ocean ridge basalts (MORB) that are depleted in incompatible rare earth elements. In detail, the radiogenic isotope signature of Ninetyeast Ridge basalts is most similar to lavas from Kerguelen Island; however, Kerguelen lavas exhibit considerable isotopic heterogeneity (Figs. 9 and 10; Mahoney et al., 1983; Weis et al., 1987).

3. Relatively "evolved" lavas may characterize Ninetyeast Ridge. At Sites 214 and 216 the recovered lavas are ferrobasalts, and at Site 214 these are overlain by oceanic andesite (e.g., Frey et al., 1977; Ludden et al., 1980).

When coupled with the northward age increase of the uppermost basement, the isotopic data favor formation of Ninetyeast Ridge as a hot-spot trace resulting from the northward movement of the Indian plate over a hot spot related to Kerguelen Island (Duncan, 1978; Mahoney et al., 1983).

\section{Questions to be Answered by Leg 121 Basement Drilling}

1. Is there a systematic variation in age and isotopic character between basement sites on Ninetyeast Ridge? The limited 


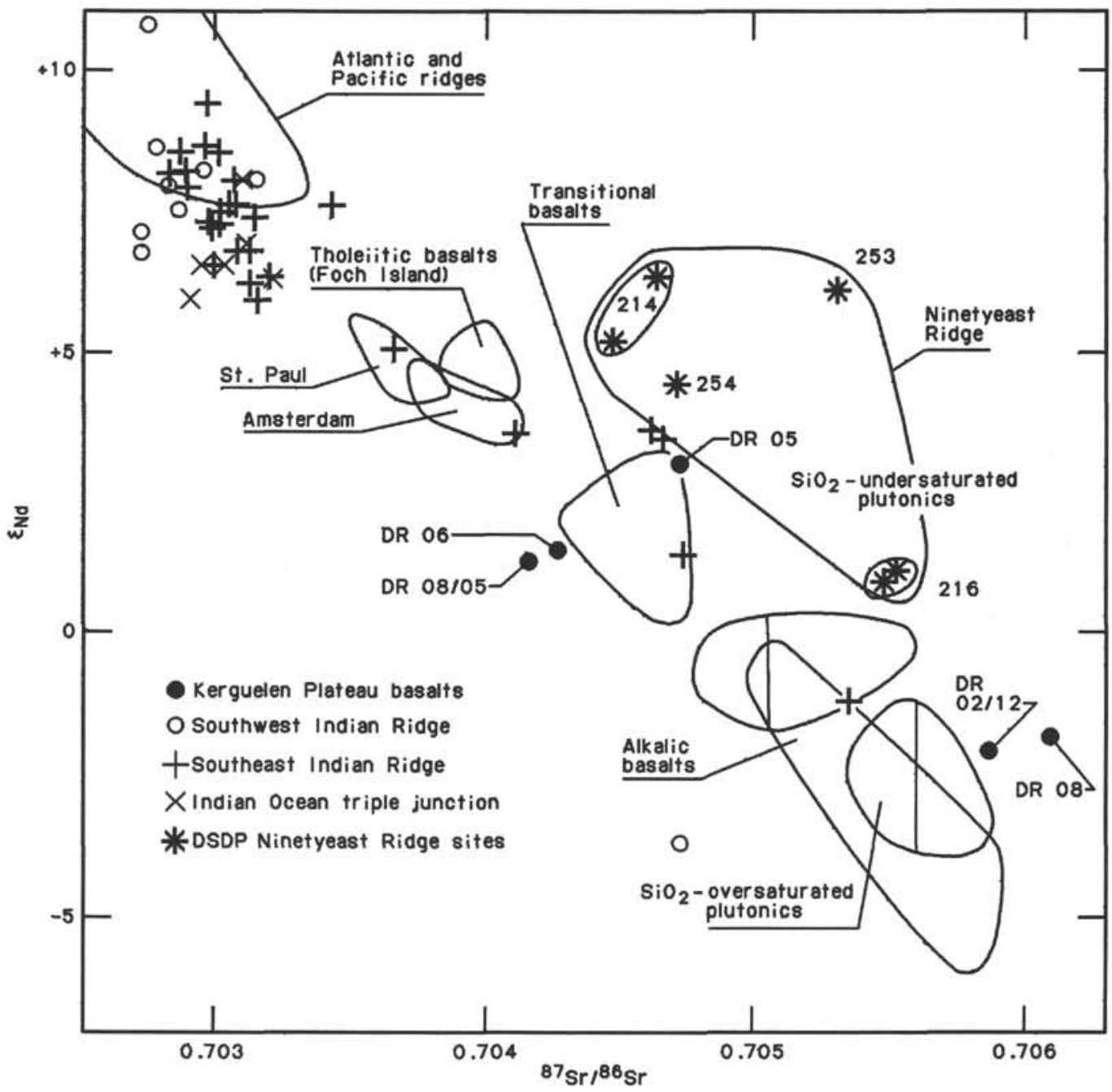

Figure 9. An elongated but nonoverlapping field for samples from Ninetyeast Ridge and Kerguelen Plateau plots for ${ }^{143} \mathrm{Nd} /{ }^{144} \mathrm{Nd}$ vs. ${ }^{87} \mathrm{Sr} /{ }^{86} \mathrm{Sr}$. It is not certain if the elevated ${ }^{87} \mathrm{Sr} /{ }^{86} \mathrm{Sr}$ for Ninetyeast Ridge reflects alteration or a real difference from Kerguelen Plateau. DSDP Sites 214 and 216 are isotopically distinct also. Compared to Figure 10 , this plot does not clearly show the differences between recent Indian spreading-ridge basalts and Pacific-Atlantic MORB, and the differences between Kerguelen and Amsterdam-St. Paul basalts are less. DR = dredge samples obtained during Marion Dufresne Cruise 48. After D. Weis (unpubl. data).

isotopic data for the Ninetyeast lavas recovered by DSDP drilling show that each of the sites is isotopically distinct (Figs. 9 and 10 ), with the most enriched characteristics (least like MORB) at the northernmost Site 216. However, the data are insufficient to determine whether this variation is systematic. Basement recovery at three additional Ninetyeast Ridge sites on ODP Leg 121 will enable evaluation of geochemical changes on an extended time scale (tens of million of years) and further test the isotopic similarity of Ninetyeast and Kerguelen lavas. In addition, improvements in analytical techniques for extracting the magmatic isotope signature from altered seafloor rocks (e.g., Mahoney, in press) will enable more thorough isotopic characterization of the basement rocks recovered by ODP and DSDP drilling than was previously available.

The isotopic data obtained for the Ninetyeast Ridge basement lavas will also have broader implications because oceanic lavas in the Indian Ocean, as a whole, have geochemical characteristics distinct from most Pacific and Atlantic oceanic basalts (e.g., Hart, 1984). An understanding of the origin and evolution of Ninetyeast Ridge will aid in understanding the larger scale problem of why the Indian Ocean lavas are geochemically distinct.

2. Does Ninetyeast Ridge contain an unusually high proportion of relatively evolved rocks? The recovery of evolved lavas, ferrobasalt, and oceanic andesites at DSDP Sites 214 and 216 may have important implications. These two sites are separated by $13^{\circ}$ latitude and perhaps in age by $22 \mathrm{~m}$.y. (Duncan et al., in press). It is possible that these evolved lavas are characteristic of the uppermost parts of Ninetyeast Ridge. The extensive meltmineral segregation required to form ferrobasalt and associated andesite requires a tectonic environment in which magma storage regions are able to cool significantly without replenishment by primitive magma. Such environments are rare on the midoceanic ridges and are more commonly associated with volcanic islands. One possible explanation for the observed Ninetyeast Ridge basalts is that these evolved lavas formed in isolated 


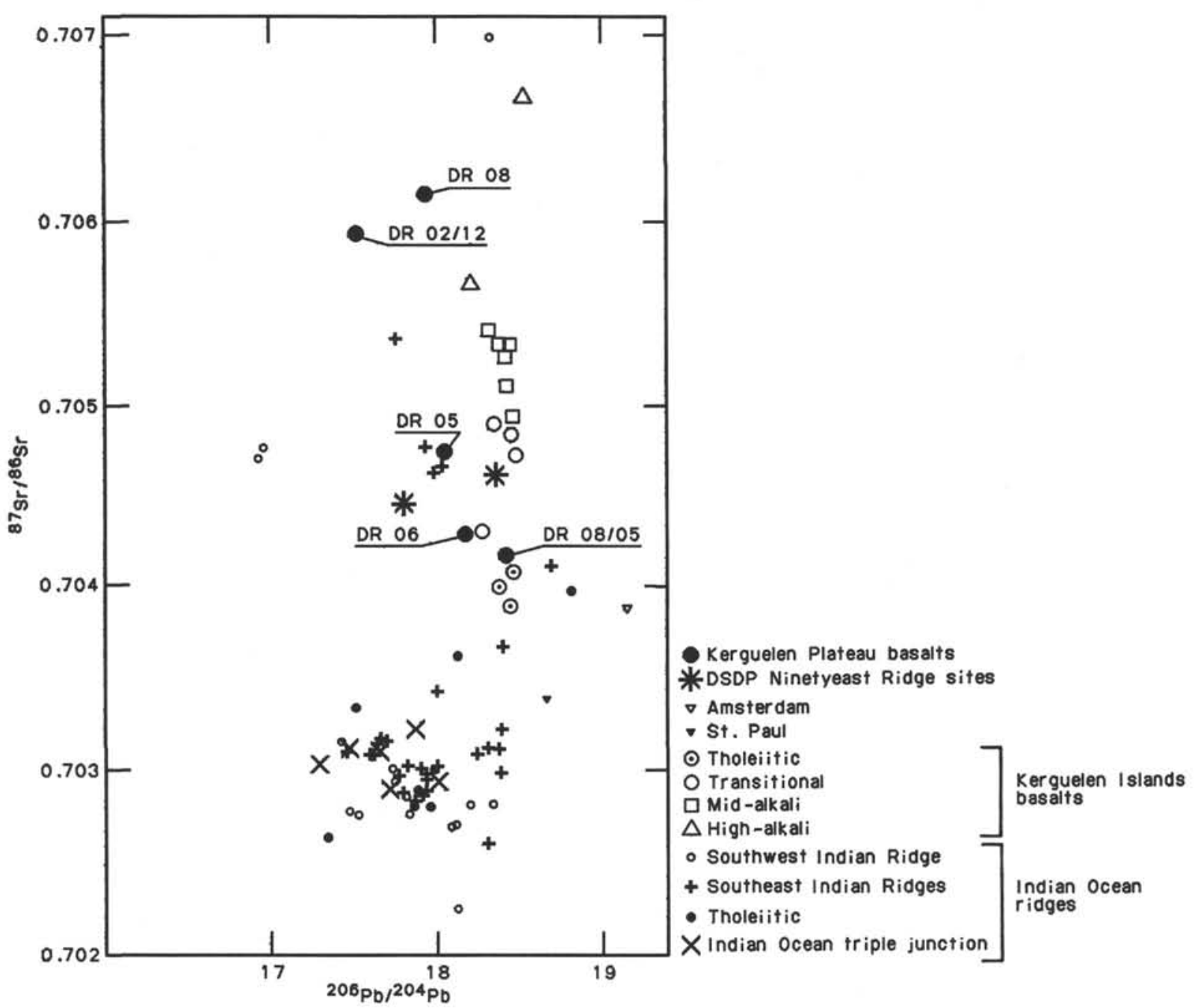

Figure 10. Most Indian Ocean mid-ocean ridge basalts (MORB; i.e., formed at a spreading axis) are displaced to higher ${ }^{87} \mathrm{Sr} /{ }^{86} \mathrm{Sr}$ and lower ${ }^{206} \mathrm{~Pb} /{ }^{204} \mathrm{~Pb}$ values relative to Pacific and Atlantic MORB. Kerguelen Plateau basalts plot in an unusual location relative to those from other Indian Ocean islands, such as St. Paul and Amsterdam. Although based on data for only two samples, the Ninetyeast lavas are similar to the Kerguelen basalts. DR = dredge samples obtained during Marion Dufresne Cruise 48. After D. Weis (unpubl. data).

magma chambers as a result of low magma-production rates as the site moved northward off the hot spot.

Investigations in Hawaii show that important petrologic and geochemical trends can be defined with relatively short sections (on the order of $100 \mathrm{~m}$ ), particularly in the waning stages of volcanic activity (Figs. 11 and 12). This small-scale characterization can be done only if the stratigraphic order of the samples is known. Dredging does not provide the stratigraphic control necessary to determine vertical geochemical variations within the same section. Therefore, drilling slightly deeper holes $(>100 \mathrm{~m})$ along Ninetyeast Ridge may provide additional insight into the last stages of volcanism that built the ridge.

3. Can the composition of the basement lavas be related to that of the overlying pyroclastic rocks? We anticipated that the section immediately overlying the basement at all the proposed sites would contain significant pyroclastic sequences. Interpretation of the seismic record at the proposed location of Site 757 on the central part of the ridge suggested that there was a significant chance of drilling intercalated lavas and pyroclastics. An objective of coring those sediments was to determine how this later volcanism on the ridge relates temporally and perhaps chemically to the basement lavas cored at those sites.

The three Ninetyeast Ridge basement sites drilled on Leg 121 have predicted upper basement ages of 49 to $80 \mathrm{Ma}$ (fig. 2 of Duncan et al., in press). Study of these basement cores will provide a sampling density sufficient to (1) narrowly constrain the northward increase in age; (2) evaluate the relative abundance of highly evolved lavas in the uppermost basement; and (3) define temporal geochemical changes in the southern part of the ridge. In addition, penetration and recovery to a depth of more than $50 \mathrm{~m}$ in basement provides geochemical data for evaluating temporal changes at a single site. By analogy with Hawaiian volcanism, changes in lava type and composition are expected as a site moves away from the principal source of magma production 


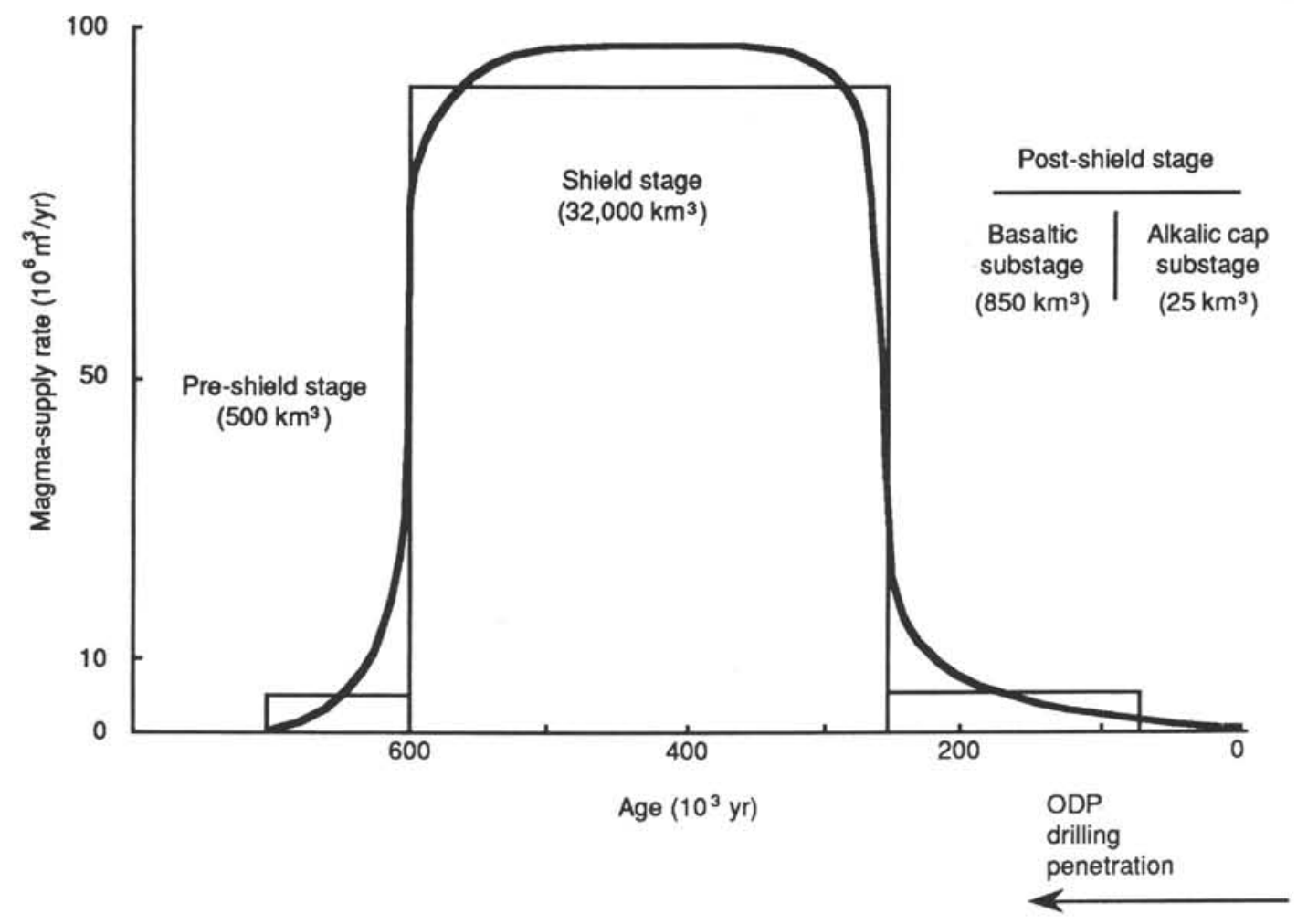

Figure 11. The magma-supply rate as a function of time during construction of Hawaiian volcanoes. The HawaiianEmperor hot-spot trend is one analog model for the Ninetyeast Ridge, although there are important differences in the thickness of the original crust through which the volcanism passed. Figure adapted from Wise (1987) and Frey et al. (in press). The $150 \mathrm{~m}$ of basement penetration samples the extreme right side of the diagram, as indicated by the arrow.

(e.g., Chen and Frey, 1985). By analogy with Icelandic volcanism, the intensity of a plume waxes and wanes on the scale of a few million years, and systematic geochemical changes are expected (e.g., Hanan and Schilling, 1986, 1987).

\section{Northward-Motion Objectives}

A primary tectonic objective of drilling on Ninetyeast Ridge is to complete a high-resolution study of the northward motion of India by studying the paleomagnetic inclinations of the recovered sedimentary and basement rocks. These results will be combined with similar results obtained from the Chagos-Laccadive Ridge on ODP Leg 115 (Duncan et al., in press) to improve our understanding of the Himalayan Orogeny and the sedimentary and tectonic histories of the surrounding basins.

\section{Results from Previous Studies}

Geological discussions of the Himalayan Orogeny put the time of initial collision somewhere in the Paleogene. The differences in exact timing seem to arise from two factors: which part of the suture is considered and whether reference is made to the initial collision of a leading block (island arc or microcontinent) or to the final continent to continent collision.

There is a stronger case to be made for earlier initial collision in the west than in the east. In the Ladakh region, stratigraphic evidence suggests that parts of the Asian accretionary wedge south of Tibet were emplaced onto Greater India by the early Paleocene (Fuchs, 1983). This event was followed by later obduction of the Zhob Valley ophiolites during the Paleocene or early Eocene (Alleman, 1979). Geological evidence in the Lhasa region suggests that Asian sediments were emplaced onto Greater India before Eocene time (Burg and Chen, 1984; Allègre et al., 1984), somewhat later than the analogous events to the west.

Paleomagnetic studies of the northward motion of India indicate that an abrupt slowing (from $\sim 15$ to $\sim 5 \mathrm{~cm} / \mathrm{yr}$ ) took place between 40 (Molnar and Tapponnier, 1975; Peirce, 1978; Fig. 13) and $50 \mathrm{Ma}$ (Patriat and Achache, 1984; Figs. 14 and 15). Either result implies that India's deceleration took place several million years later than collision.

Klootwijk et al. (1985) synthesized the preceding observations into a model suggesting that suturing migrated eastward during the Paleocene and was completed by the early Eocene. Further convergence was accommodated by lateral extrusion of continental blocks in a manner similar to the analog clay models of Tapponnier et al. (1986), followed by oroclinal bending and continental underthrusting since the late Miocene. Patriat and Achache (1984) proposed a somewhat different synthesis that puts continental subduction somewhat later (middle Eocene), followed by underthrusting and internal deformation during the late Eocene and subsequent lateral extrusion following the Tapponnier et al. (1986) model.

Any model must be consistent with three critical pieces of stratigraphic evidence indicative of the time of earliest uplift of the Himalayas, namely:

1. The age of the Rawalpindi Group (first molasse sediments) in Pakistan is Miocene, and it rests on Eocene or older rocks, suggesting that the unconformity associated with initial loading of the Indian plate is of Oligocene age (Igbal and Shah, 1980). 


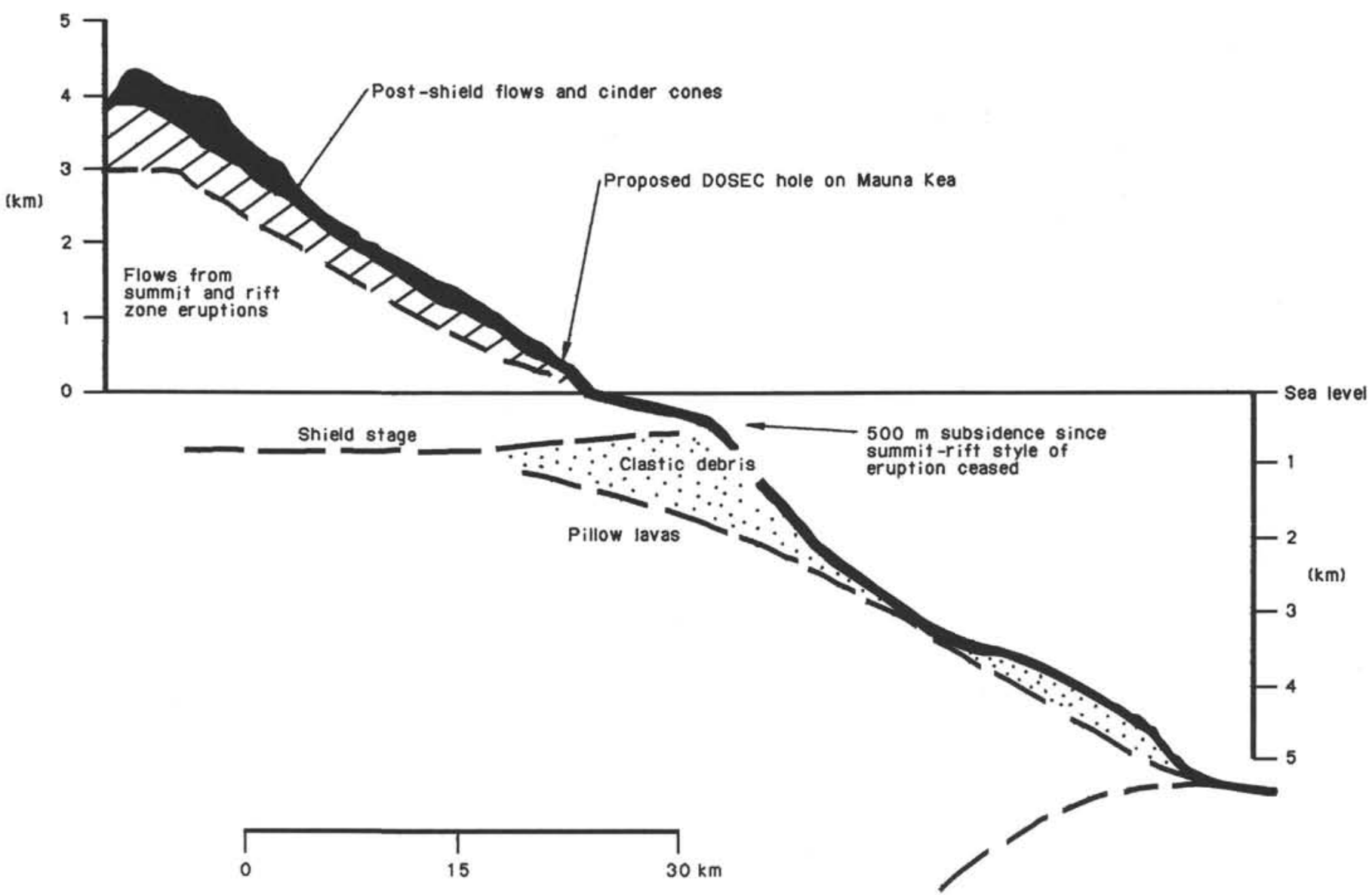

Figure 12. Cross section of an Hawaiian volcanic edifice, based on a study of Mauna Kea Volcano, Hawaii. The volcanic section on Ninetyeast Ridge may be similar in form, but it subsided below sea level and was covered by pelagic sedimentation. Figure adapted from Wise (1987) and Frey et al. (in press).

2. The Bengal Fan was well established by early Miocene time (ODP Leg 116 Shipboard Scientific Party, 1987).

3. The rifting of the South China Sea margin occurred in the Oligocene in response to extrusion tectonics associated with the Himalayan Orogeny (fig. 10 of Tapponnier et al., 1986).

\section{Questions to be Answered by Leg 121 Drilling}

Presumably the deceleration of the Indian plate was related to a change in the balance of the plate-driving forces. Can we improve our understanding of these forces by combining a study of the details of the slowing with the onshore evidence of collision?

Was the deceleration coincident with the onset of the extrusion of continental blocks resulting in the widespread deformation of southern Asia, as suggested by the first model. Or was the deceleration related to the onset of continental subduction, as in the second model. Was the deceleration abrupt, or did it take place over some $10 \mathrm{Ma}$ ? The answers to these questions may provide major constraints for models of plate-driving forces and for models of continental collision.

What was the nature and timing of the terrigenous component of sedimentation after collision? Because of its proximity to the Ganges-Brahmaputra drainage system, Site 758 , on the northern end of Ninetyeast Ridge, contains a sedimentary record of at least the recent uplift history. The site was located above the sedimentary distribution channels of the Bengal Fan to ensure that the section would be thin enough to penetrate, that it would be not interrupted by turbidites, and that recovery would not be impeded by extensive sandy intervals.

\section{Paleoceanographic and Paleoclimatologic Objectives}

Another Leg 121 objective was to establish a south-north transect of sites with high core recovery in the eastern Indian Ocean, which would provide appropriate data for studying spatial and temporal paleontological distributions and paleoclimatologic changes. This work is especially important for establishing bridging connections between different fossil assemblages, particularly between those of austral high latitudes and those of subtropical and tropical latitudes upon which commonly used biostratigraphic time scales (e.g., Berggren et al., 1985; Blow, 1969; Bolli et al., 1985) are based. This transect extends the results from ODP Legs 119 and 120 in the southern Indian Ocean to the north and parallels the transect obtained by ODP Leg 115 in the western Indian Ocean.

\section{Results from Previous Studies}

\section{Paleoceanography}

Present-day middle- and low-latitude Indian Ocean water masses are separated into three zones (Bé and Hutson, 1977): 


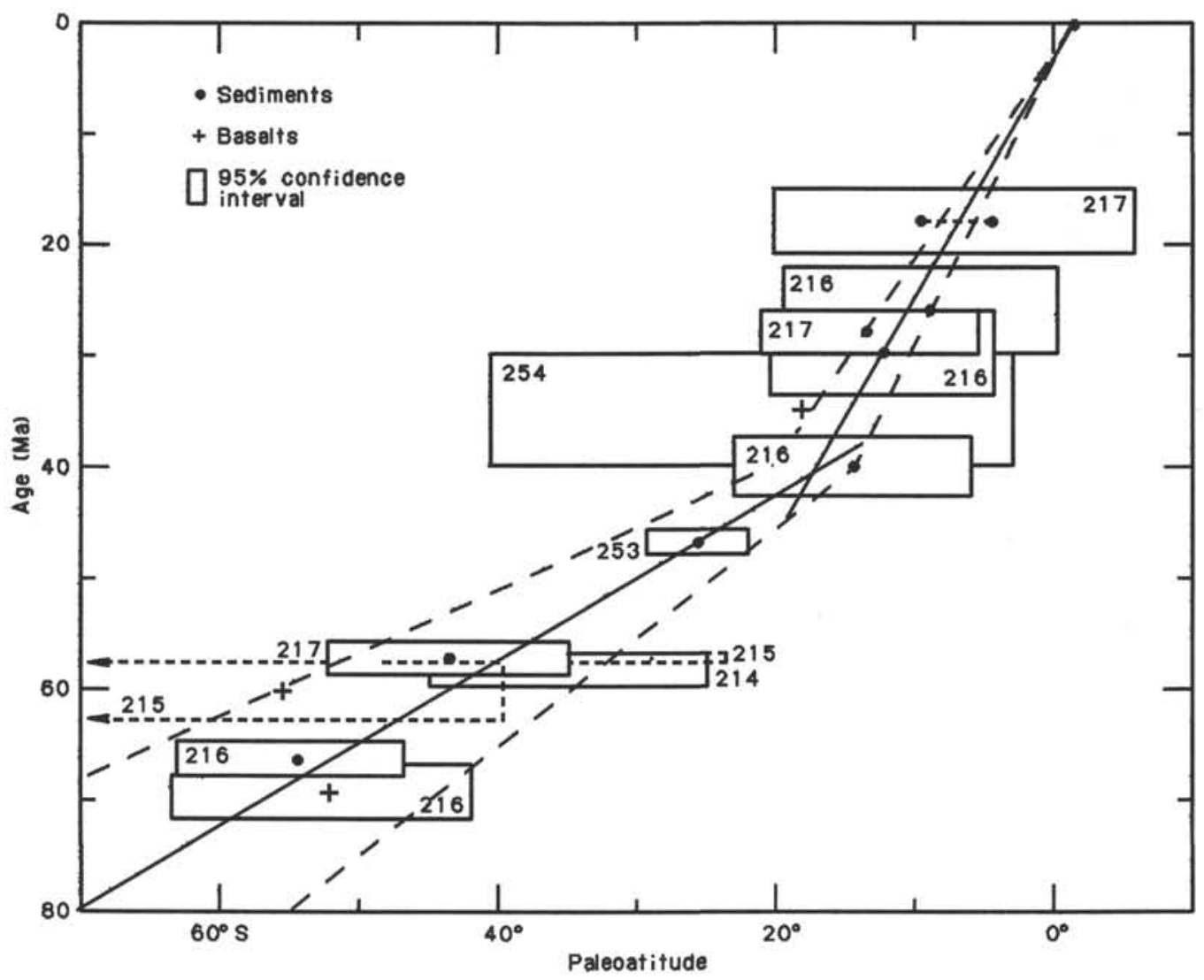

Figure 13. Paleomotion of DSDP Site 216 based on paleolatitudes from all of the sites on Ninetyeast Ridge. Only paleolatitudes based on at least eight samples are plotted. For sites other than Site 216, a correction equal to the present latitude difference from Site 216 was applied. Site 215 data are not consistent with those from the Ninetyeast Ridge sites, and the confidence interval is shown with a dotted line. The solid lines indicate rates of northward motion of India obtained by weighted least-squares linear regression. The dashed lines indicate the $95 \%$ confidence region for the position of Site 216 , assuming Student t-statistics apply to the rates of motion. The calculated rates are $0-40 \mathrm{Ma}, 5.2 \pm 0.8 \mathrm{~cm} / \mathrm{yr}(\mathrm{N}=6$, through the origin) and 40 $70 \mathrm{Ma}, 14.9 \pm 4.5 \mathrm{~cm} / \mathrm{yr}(\mathrm{N}=6)$ (from Peirce, 1978).

Equatorial Water, Central Water, and a Tropical-Subtropical Transition Zone. Two major systems characterize Indian Ocean circulation: the seasonally changing monsoon gyre in the equatorial region and the subtropical anticyclonic gyre of the Central Water region (Wyrtki, 1973). High-nutrient, low-oxygen waters are described by Wyrtki (1973) as characterizing the monsoonal gyre in the northern Indian Ocean, with low-nutrient, high-oxygen waters in the subtropical gyre. Sediment patterns on either side of Ninetyeast Ridge reflect this boundary between high and low productivity, with siliceous sediments present in the area of high productivity north of about $15^{\circ} \mathrm{S}$ and pelagic clays characterizing areas of low productivity to the south.

The sediment record from various Indian Ocean sites indicates oceanic conditions in the past varied significantly from present-day conditions. Müller (1977) reported that lower water temperatures during the Oligocene might have contributed to low production of calcareous microfossils, lower species diversity, and condensed sections resulting from dissolution at or below the CCD in the deep-sea basins of the Indian Ocean. Kennett and Burns (1972) suggested that such conditions resulted from the influx of cold circumpolar water masses deflected into the lower latitudes of the Indian Ocean by Australia. These cold-water masses were responsible for strong bottom-current activity that, through erosion and/or winnowing, resulted in lower Oligocene sedimentary gaps. This flux of cold water reported by Kennett and Burns (1972) and the circulation changes resulting from the final establishment of the Antarctic Circumpolar Current at the end of the Oligocene should be reflected in the flora and fauna of Broken Ridge and Ninetyeast Ridge.

Cooling during the late Miocene moved the area of optimum conditions for the foraminifer genus Globoquadrina north of $25^{\circ} \mathrm{S}$ (Vincent, 1977). Müller (1977) reported an increase in diversity and productivity in nannofossils, notably discoasters, ceratoliths, and scyphospheres, from the middle Miocene to the lower Pliocene. Calcareous nannofossil and foraminifer assemblages at most Indian Ocean DSDP sites reflect tropical to subtropical conditions during that time. The onset of the modern equatorial circulation pattern, concurrent with significant ice accumulation on Antarctica during the late Miocene, is marked by an increase in sediment-accumulation rates and in the abundance of siliceous fossils at all low-latitude sites in the Indian Ocean (Vincent, 1977). 

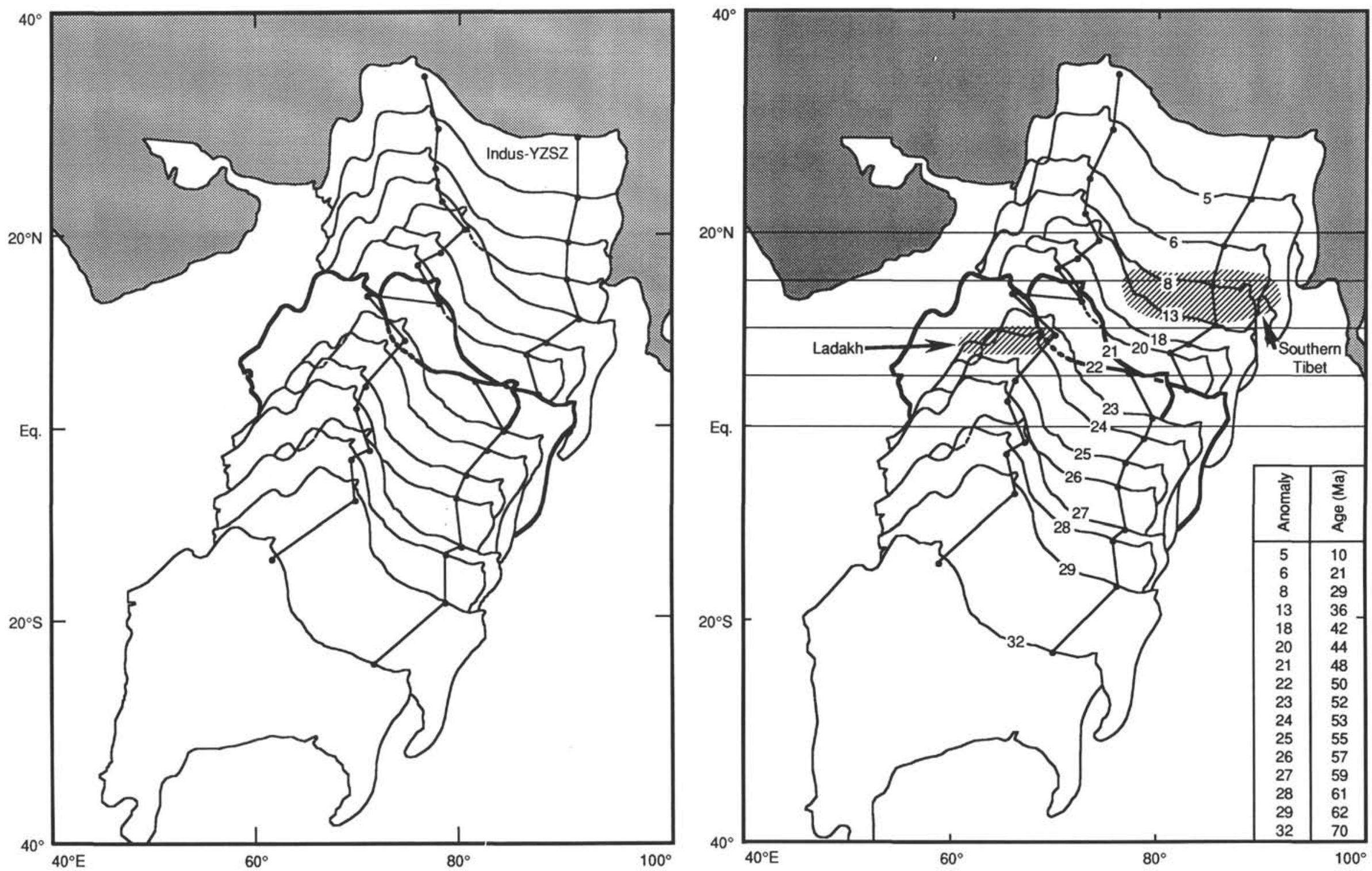

Figure 14. Cenozoic northward drift of India. The northern limit of the Indian continent is taken to be the presence of the Indus-YZSZ. The passive margins are drawn at the 500-m isobath (represented at anomaly 32 time). Also plotted is the motion of two points on the Indian continent near the northern margin: in Ladakh (34.34' $\left.\mathrm{N}, 76^{\circ} 7^{\prime} \mathrm{E}\right)$ and on the suture zone near the position of L ( Cof India with respect to Eusasia, which is kept arbitrarily fixed in its present position. B. Absolute motion of lndia in re 

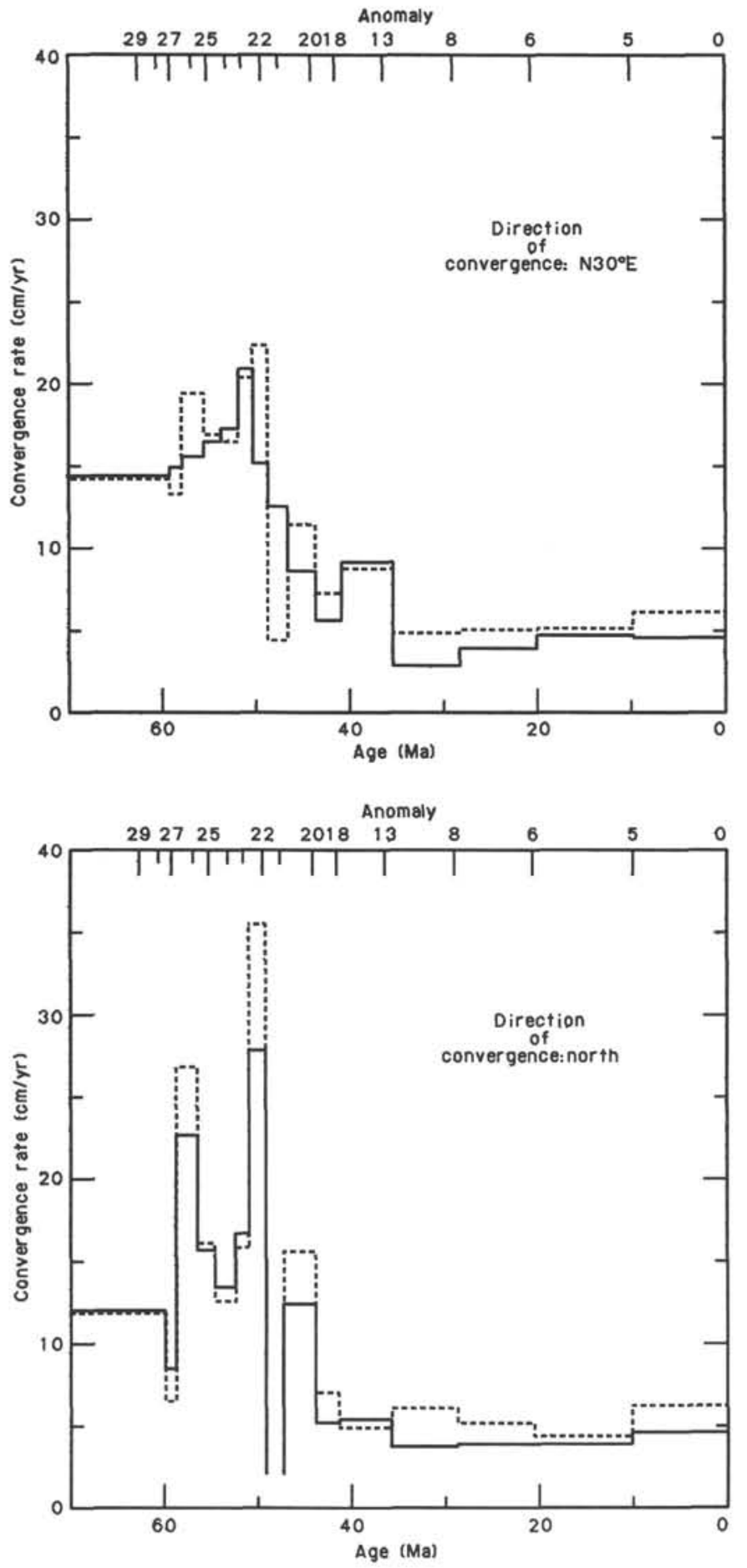

Figure 15. Computed rates of convergence between the Indian and Eurasian plates during the Cenozoic at two arbitrary points $\left(5^{\circ} \mathrm{N}, 75^{\circ} \mathrm{E}\right.$, solid line; $5^{\circ} \mathrm{N}, 90^{\circ} \mathrm{E}$, dashed line) along two directions. The rate of subduction perpendicular to the trench is indicated for a subduction zone near the southern margin of Eurasia trending N120 $\mathrm{E}$ (top) or east-west (bottom) (from Patriat and Achache, 1984).

The core recovery of DSDP Leg 22 from Ninetyeast Ridge was far from complete. The plan for Leg 121 was to recover a complete section at the northern site (proposed Sites NER-1A for the Neogene and NER-1B for the Paleogene were subsequently combined into Site 758) and at the central site (proposed Site NER-2, Site 757). Original planning deemed the sec- tion at the southern site (proposed Site NER-5, Site 756) as not particularly useful because the section there is thin and much of it was expected to be volcaniclastic. Subsequent discussions aboard ship, however, suggested that this location might provide a pivotal bridging point in the transition zone between the temperate austral assemblages common at higher latitudes and the subtropical forms on which most biostratigraphic time scales depend. The sites from Broken Ridge $\left(30^{\circ} \mathrm{S}\right)$ plus those on Ninetyeast Ridge offer an excellent opportunity to promote further study on the evolution and establishment of the present Indian Ocean circulation patterns and sea surface conditions using temperature-sensitive planktonic foraminifers, calcareous nannofossils, and siliceous microplankton groups.

\section{Paleoclimatology}

Eolian dust from pelagic sediments provides a quantitative record of both the intensity of zonal winds and the aridity of the eolian source area. Continuous Cretaceous to Holocene records from the Northern Hemisphere (Rea et al., 1985) document generally increasing wind intensity and growing continental aridity concurrent with middle to late Cenozoic polar cooling. A significant change in wind intensity appears to have occurred during the early Eocene, shifting from more vigorous Cretaceous and Paleocene circulation to greatly reduced Eocene and Oligocene circulation. These data, recently confirmed from the North Atlantic (McCave and Lever, 1986), are contrary to the general perception of rather sluggish oceanic circulation during the Late Cretaceous and earliest Tertiary. Data from the North Pacific are based mainly on red clay cores, and consequently, the atmospheric circulation history inferred from them is not well tied to the standard oxygen isotope history used by paleoceanographers.

Results of similar efforts based on DSDP Leg 92 drilling in the South Pacific and tied to standard fossil zonations indicate that important changes in atmospheric circulation may not coincide with the episode of ice volume increase recorded in middle Miocene sediments. There is, however, a close correspondence between the middle Miocene atmospheric circulation record and the record of equatorial sea surface productivity (Rea and Bloomstine, 1986). Furthermore, results from the South Pacific indicate no change in atmospheric circulation that corresponds with the onset of Northern Hemisphere glaciation recorded in mid-Pliocene sediments.

\section{Questions to be Answered by Leg 121 Drilling}

The next step in determining the Cenozoic record of atmospheric circulation is to recover continuous, stratigraphically useful sections of pelagic sediment along a south-north transect across the Southern Hemisphere. The southern Indian Ocean is the ideal location because it lies between the deserts of Africa and Australia, implying an adequate source of dust, regardless of wind direction. Site locations on top of Ninetyeast Ridge ensure minimal abyssal reworking and fewer unrecognized complications from hemipelagic input. Cores recovered with the hydraulic piston corer/advanced piston corer system will provide the requisite biostratigraphic, magnetostratigraphic, and isotopic stratigraphy with which to interpret the eolian record for this part of the Southern Hemisphere. A space-time backtrack plot of drill site locations, including the Leg 121 sites (Fig. 16), shows that the new samples fill gaps in the data for the Southern Hemisphere trade winds and westerlies throughout the $\mathrm{Ce}$ nozoic.

The Leg 121 samples will be used to address the following questions:

1. When did the great deserts of Australia and Africa evolve?

2. Given that atmospheric circulation is a function of a latitudinal (pole to equator) temperature gradient, how does the eo- 


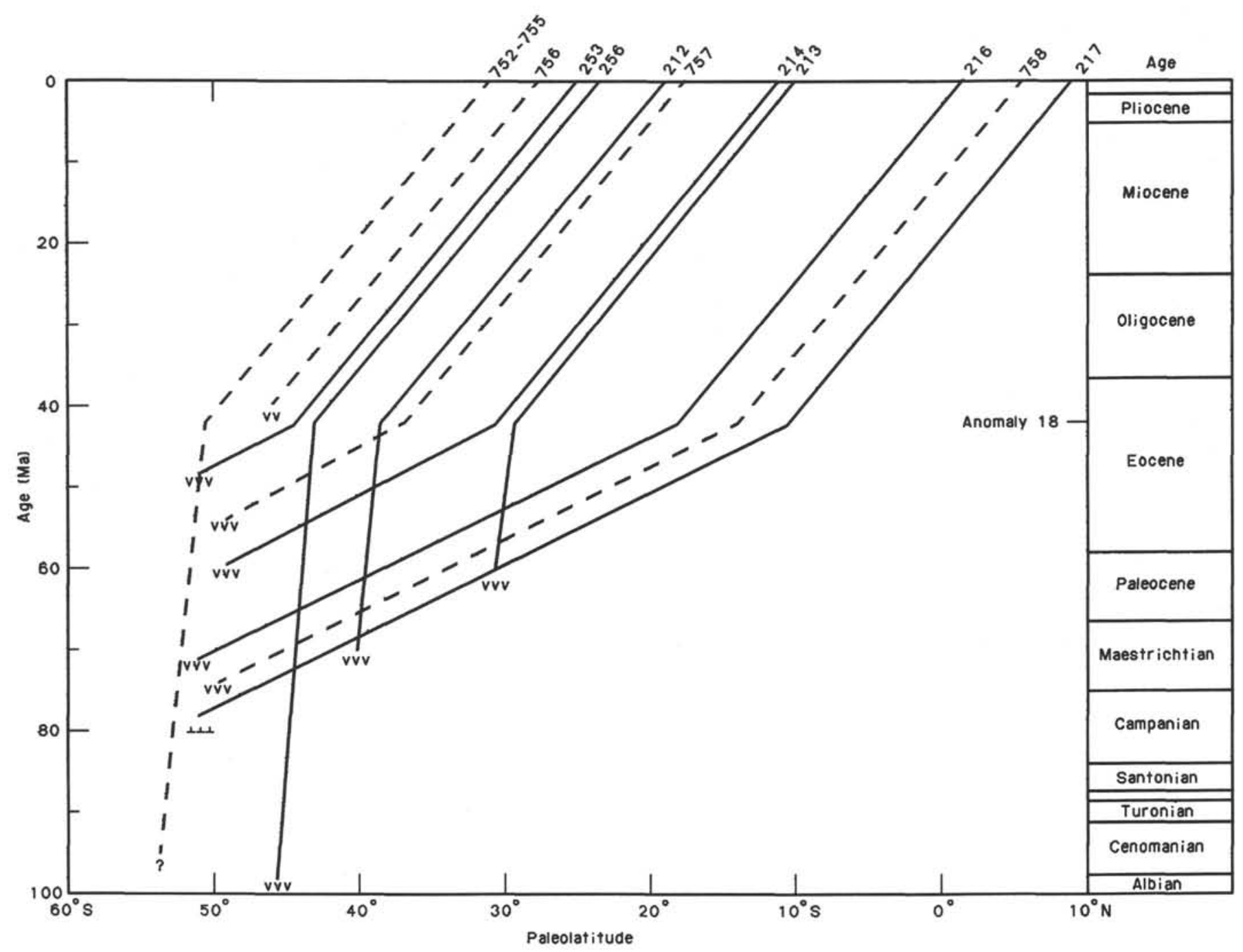

Figure 16. Predicted paleolatitudes for ODP Leg 121 sites and nearby DSDP sites, based on Peirce (1978) and J.-Y. Royer (pers. comm., 1988).

lian record compare with the oxygen isotope record of ice volume?

3. How have the zonal wind belts migrated north and south through time? What is the record in the Southern Hemisphere of the large, early Eocene changes in atmospheric circulation that are recorded at Northern Hemisphere locations?

4. Does the onset of glaciation in the Northern Hemisphere have any effect on the circulation of the Southern Hemisphere?

A unifying theme to the objectives of most of the ODP sites in the northern Indian Ocean is to study the impact of the uplift of the Himalayas and the Tibetan Plateau on sedimentation rates (increased terrigenous input) and the development of the monsoonal climate regime (which is ultimately driven by the seasonal differences in air temperature over the Indian Ocean and the Tibetan Plateau). ODP Leg 116 (Cochran, Stow, et al., 1989) focused on the Bengal Fan deposits derived from Himalayan uplift, and ODP Leg 117 (ODP Leg 117 Shipboard Scientific Party, 1988) studied the history of monsoon development in the Arabian Sea.

Site 758 , at the northern end of Ninetyeast Ridge, provides an opportunity to complement those studies at a location where the Himalayan component of sedimentation is hemipelagic, instead of turbiditic (as at the Bengal Fan sites of ODP Leg 116).
Its low-latitude location in proximity to a sedimentary source area, which was probably variably affected by Pleistocene glaciation, offers a unique opportunity to study climatic variations. In this setting, the difference in the sedimentary signal between glacial and interglacial periods should be particularly dramatic. These climatic variations have been related to variations in the input of solar energy related to variations in Earth's orbital geometry (Milankovitch cycles) at other ODP sites (e.g., Srivastava, Arthur, et al., 1987). Seasonal monsoonal variations are superimposed on this glacial-interglacial pattern. Site 758 is the only ODP site that lies within the influence of the monsoons to the east of the Indian subcontinent. As such, it provides an important complement to the sites west of India in the Arabian Sea. Furthermore, it offers us the opportunity to study high-resolution climatic fluctuations superimposed on longer time scale tectonic variations.

\section{General Tectonic Objectives}

There are several significant details about the tectonics of the eastern Indian Ocean that are yet to be resolved. One major problem not adequately resolved is the history of the Ninetyeast Transform Fault, which lies immediately east of Ninetyeast Ridge, south of $7^{\circ} \mathrm{S}$. The spreading history associated with this major fault has been discussed by Sclater and Fisher (1974), 
Luyendyk (1977), Peirce (1978), Schlich (1982), and Liu et al. (1983), among others. Royer et al. (in press) presented a complete model for the growth of this fault, but the implications of their model need to be integrated with models for the formation of Ninetyeast Ridge. The transit of JOIDES Resolution between Sites 756 and 757 was in a little-traveled part of the world (see Fig. 1, "Ninetyeast Ridge Underway Geophysics" chapter, this volume). A magnetic profile of the ocean crust recorded immediately east of Ninetyeast Ridge should supply critically needed constraints for kinematic plate models.

The study of breakouts as an indicator of in-situ stress is also related to plate kinematic models. Originally, this work was planned for Site 757 using the borehole televiewer in combination with other downhole logs and carried as a contingency option at Site 758 . When drilling at Site 757 was terminated prematurely, the logging objectives became part of the drilling plan for Site 758. The measurement of in-situ stress at this location is particularly important because earthquake studies indicate that present-day deformation of the Indo-Australian plate is occurring in this region (see preceding discussion). Similar stresses, presumably related, created folds in the Bengal Fan sediments that were drilled on ODP Leg 116 (Sites 717-719, Fig. 1; Cochran, Stow, et al., 1989). The pervasive occurrence of young faults observed on the seismic data acquired during the approach survey (see "Seismic Stratigraphy" section, "Site 758" chapter, and "Ninetyeast Ridge Underway Geophysics" chapter) is a further indication of high stresses at this location.

\section{REFERENCES}

Allègre, C. J., et al., 1984. Structure and evolution of the Himalaya-Tibet orogenic belt. Nature, 307:17-22.

Alleman, F., 1979. Time of emplacement of the Zhob Valley ophiolites and Bela ophiolites, Baluchistan (preliminary report). In Farah, A., and de Jong, K. A. (Eds.), Geodynamics of Pakistan: Quetta, Pakistan (Geol. Surv. Pak.), 215-242.

Barron, J., Larsen, B., et al., 1989. Proc. ODP, Init. Repts., 119: College Station, TX (Ocean Drilling Program).

Barton, P., and Wood, R. A., 1984. Tectonic evolution of the North Sea Basin. Geophys. J. R. Astron. Soc., 79:987-1022.

Bé, A.W.H., and Hutson, W. H., 1977. Ecology of planktonic foraminifera and biogeographic patterns of life and fossil assemblages in the Indian Ocean. Micropaleontology, 23:369-414.

Berggren, W. A., Kent, D. V., Flynn, J. J., and Van Couvering, J. A., 1985. Cenozoic geochronology. Geol. Soc. Am. Bull., 96:1407-1418.

Blow, W. H., 1969. Late middle Eocene to Recent planktonic biostratigraphy. In Bronnimann, P., and Renz, H. H. (Eds.), Proc. Int. Conf. Planktonic Microfossils, Ist, Geneva, 1967, 1:199-421.

Bodine, J. H., Steckler, M. S., and Watts, A. B., 1981. Observations of flexure and the rheology of oceanic lithosphere. J. Geophys. Res., $86: 3695-3707$.

Bolli, H. M., Saunders, J. B., and Perch-Nielsen, K. (Eds.), 1985. Plankton Stratigraphy: Cambridge (Cambridge Univ. Press).

Bowin, C. O., 1973. Origin of Ninetyeast Ridge from studies near the equator. J. Geophys. Res., 78:6029-6043.

Burg, J. P., and Chen, G. M., 1984. Tectonics and structural zonation of southern Tibet, China. Nature, 311:219-223.

Chen, C.-Y., and Frey, F. A., 1985. Trace element and isotopic geochemistry of lavas from Haleakala Volcano, east Maui, Hawaii: implications for the origin of Hawaiian basalts. J. Geophys. Res., 90: 8743-8768.

Cochran, J. R., Stow, D.A.V., et al., 1989. Proc. ODP, Init. Repts., 116: College Station, TX (Ocean Drilling Program).

Davies, T. A., Luyendyk, B. P., et al., 1974. Init. Repts. DSDP, 26: Washington (U.S. Govt. Printing Office).

Davis, E. E., and Lister, C.R.B., 1974. Fundamentals of ridge crest topography. Earth Planet. Sci. Lett., 21:405-413.

Detrick, R. S., Sclater, J. G., and Thiede, J., 1977. The subsidence of aseismic ridges. Earth Planet. Sci. Lett., 34:185-196.

Duncan, R. A., 1978. Geochronology of basalts from the Ninetyeast Ridge and continental dispersion in the eastern Indian Ocean. $J$. Volcanol. Geotherm. Res., 4:283-305.
1981. Hotspots in the Southern Oceans: an absolute frame of reference for motion of the Gondwana continents. Tectonophysics, $74: 29-42$.

Duncan, R. A., Backman, J., Macdonald, A., et al., in press. Réunion hotspot activity through Tertiary time: initial results from the Ocean Drilling Program, Leg 115. J. Volcanol. Geotherm. Res.

Fowler, S., and McKenzie, D., in press. Flexural studies of the Exmouth and Rockall plateaus using SEASAT altimetry. Mar. Geophys. Res.

Frey, F. A., Dickey, J. S., Thompson, G., and Bryan, W., 1977. Eastern Indian Ocean DSDP sites: correlations between petrology, geochemistry and tectonic setting. In Heirtzler, J. R., Bolli, H. M., Davies, T. A., Saunders, J. B., and Sclater, J. G. (Eds.), Indian Ocean Geology and Biostratigraphy: Washington (Am. Geophys. Union), 189-257.

Frey, F. A., Wise, W., Garcia, M. O., West, H., Kennedy, A., and Kwon, S. T., in press. Evolution of Mauna Kea Volcano, Hawaii: petrologic and geochemical constraints on postshield volcanics. $J$. Geophys. Res.

Fuchs, G., 1983. Events along the Indus Suture zone as documented in the geology of Zanskar (Ladakh-Himalaya). Terra Cognita, 3:212.

Hanan, B. B., and Schilling, J.-G., 1986. The source origin of Iceland basalt volcanism: $\mathrm{Pb}$ isotopes in the eastern Iceland Tertiary section. EOS, Trans. Am. Geophys. Union, 67:409-410. (Abstract)

1987. $\mathrm{Pb}$ isotope evolution of the Iceland Plume. EOS, Trans. Am. Geophys. Union, 68:437. (Abstract)

Hart, S., 1984. A large-scale isotope anomaly in the Southern Hemisphere mantle. Nature, 309:753-757.

Igbal, M.W.A., and Shah, S.M.I., 1980. Guide to the stratigraphy of Pakistan. Geol. Invest. Ser. Geol. Surv. Pak., Interim Geol. Rep., 31.

Kennett, J. P., and Burns, R. E., 1972. Australian-Antarctic continental drift, paleocirculation changes and Oligocene deep erosion. Nature, 239:51-55.

Klootwijk, C. T., Conaghan, P. J., and Powell, C. McA., 1985. The Himalayan Arc: large-scale continental subduction, oroclinal bending and back-arc spreading. Earth Planet. Sci. Lett., 75:167-183.

Leclaire, L., Bassias, Y., Denis-Clocchiatti, M., Davies, H., Gautier, I., Gensous, B., Giannesini, P.-J., Patriat, P., Segoufin, J., Tesson, M., and Wannesson, J., 1987. Lower Cretaceous basalt and sediments from the Kerguelen Plateau. Geo Mar. Lett., 7:169-176.

Liu, C. S., Curray, J. R., and McDonald, J. M., 1983. New constraints on the tectonic evolution of the eastern Indian Ocean. Earth Planet. Sci. Lett., 65:331-342.

Ludden, J. N., Thompson, G., Bryan, W. B., and Frey, F. A., 1980. The origin of lavas from the Ninetyeast Ridge, eastern Indian Ocean: an evaluation of fractional crystallization models. J. Geophys. Res., 85: 4405-4420.

Luyendyk, B. P., 1977. Deep sea drilling on the Ninetyeast Ridge: synthesis and a tectonic model. In Heirtzler, J. R., Bolli, H. M., Davies, T. A., Saunders, J. B., and Sclater, J. G. (Eds.), Indian Ocean Geology and Biostratigraphy: Washington (Am. Geophys. Union), 165187.

Luyendyk, B. P., and Rennick, W., 1977. Tectonic history of aseismic ridges in the eastern Indian Ocean. Geol. Soc. Am. Bull., 88:13471356 .

Mahoney, J. J., in press. An isotopic survey of Pacific Ocean plateaus: implications for their nature and origin. Am. Geophys. Union Menard Vol.

Mahoney, J. J., MacDougall, J. D., Lugmair, G. W., and Gopalan, K., 1983. Kerguelen hot-spot source for Rajmahal traps and Ninetyeast Ridge? Nature, 303:385-389.

McCave, I. N., and Lever, A., 1986. Wind vigour over the southern North Atlantic Ocean during the last 135 m.y. Int. Conf. Paleoceanogr. Abstr. Programs, Woods Hole Oceanogr. Inst., 2:54. (Abstract)

Minster, J. B., and Jordan, T. H., 1978. Present-day plate motions. J. Geophys. Res., 83:5331-5354.

Molnar, P., Pardo-Casas, F., and Stock, J., 1988. The Cenozoic and Late Cretaceous evolution of the Indian Ocean basin: uncertainties in the reconstructed positions of the Indian, African, and Antarctic plates. Basin Res., 1:23-40.

Molnar, P., and Tapponnier, P., 1975. Cenozoic tectonics of Asia: effects of a continental collision. Science, 198:419-426.

Morgan, W. J., 1981. Hotspot tracks and the opening of the Atlantic and Indian Oceans. In Emiliani, C. (Ed.), The Sea: The Oceanic Lithosphere (vol. 7): New York (Wiley), 443-487. 
Müller, C., 1977. Distribution of calcareous nannoplankton in Oligocene to Holocene sediments of the Red Sea and the Indian Ocean reflecting paleoenvironment. In Heirtzler, J. R., Bolli, H. M., Davies, T. A., Saunders, J. B., and Sclater, J. G. (Eds.), Indian Ocean Geology and Biostratigraphy: Washington (Am. Geophys. Union), 371295.

Mutter, J. C., and Cande, S. C., 1983. The early opening between Broken Ridge and Kerguelen Plateau. Earth Planet. Sci. Lett., 65:369376.

ODP Leg 116 Shipboard Scientific Party, 1987. Collisions in the Indian Ocean. Nature, 330:519-521.

ODP Leg 117 Shipboard Scientific Party, 1988. Milankovitch and monsoons. Nature, 331:663-664.

Parker, R. L., and Oldenburgh, D. W., 1973. A thermal model of oceanic ridges. Nature, 242:137-139.

Parsons, B., and Sclater, J. G., 1977. An analysis of the variation of ocean floor heat flow and bathymetry with age. J. Geophys. Res., 82:803-827.

Patriat, P., 1983. Evolution du systeme de dorsale de l'océan Indien [Thesis]. Univ. de Paris.

Patriat, P., and Achache, J., 1984. India-Eurasia collision chronology has implications for crustal shortening and driving mechanism of plates. Nature, 311:615-621

Peirce, J. W., 1977. The origin of the Ninetyeast Ridge and the northward motion of India, based on DSDP paleolatitudes [Ph.D. dissert.]. MIT/WHOI Joint Program Oceanogr.

1978. The northward motion of India since the Late Cretaceous. Geophys. J. R. Astron. Soc., 52:277-312.

Rea, D. K., and Bloomstine, M. K., 1986. Neogene history of the South Pacific trade winds: evidence for hemispherical asymmetry of atmospheric circulation. Palaeogeogr. Palaeoclimatol. Palaeoecol., 55: 55-64.

Rea, D. K., Leinen, M., and Janecek, T. R., 1985. Geologic approach to the long-term history of atmospheric circulation. Science, 227: 721-725.

Royer, J.-Y., Sclater, J. G., and Sandwell, D. T., in press. A preliminary tectonic chart of the Indian Ocean. Proc. Indian Acad. Sci., Earth Planet. Sci.

Sclater, J. G., and Fisher, R. L., 1974. The evolution of the east central Indian Ocean, with emphasis on the tectonic setting of the Ninetyeast Ridge. Geol. Soc. Am. Bull., 85:683-702.

Schlich, R., 1982. The Indian Ocean: aseismic ridges, spreading centers, and oceanic basins. In Nairn, A.E.M., and Stehli, F. G. (Eds.), Ocean Basins and Margins (vol. 6): New York (Plenum), 51-147.

Schlich, R., Wise, S. W., 1989. Proc. ODP, Init. Repts., 120: College Station, TX (Ocean Drilling Program).

Sengor, A.H.C., and Burke, K., 1978. Relative timing of rifting and volcanism on earth and its tectonic implications. Geophys. Res. Lett., 5:419-421.

Spohn, T., and Schubert, G., 1982. Convective thinning of the lithosphere: a mechanism for the initiation of continental rifting. J. Geophys. Res., 87:4669-4681.

Srivastava, S. P., Arthur, M., et al., 1987. Proc. ODP, Init. Repts., 105: College Station, TX (Ocean Drilling Program).

Stein, S., and Okal, E., 1978. Seismicity and tectonics of the Ninetyeast Ridge area: evidence for internal deformation of the Indian plate. $J$. Geophys. Res., 83:2233-2245.
Tapponnier, P., Peltzer, G., and Armijo, R., 1986. On the mechanics of the collision between India and Asia. In Coward, M. P., and Ries, A. C. (Eds.), Collision Tectonics: Sp. Publ. Geol. Soc. London, 19: 115-157.

Vail, P. R., Hardenbol, J., and Todd, R. G., 1984. Jurassic unconformities, chronostratigraphy and sea-level changes from seismic stratigraphy and biostratigraphy. In Schlee, J. S. (Ed.), Interregional Unconformities and Hydrocarbon Accumulation: AAPG Memoir, 36:129144.

Vail, P. R., Mitchum, R. M., Shipley, T. H., and Buffler, R. T., 1980. Unconformities of the North Atlantic. Philos. Trans. R. Soc. London $A, 294: 137-155$.

Vincent, E., 1977. Indian Ocean Neogene planktonic foraminiferal biostratigraphy and its paleoceanographic implications. In Heirtzler, J. R., Bolli, H. M., Davies, T. A., Saunders, J. B., and Sclater, J. G. (Eds.), Indian Ocean Geology and Biostratigraphy: Washington (Am. Geophys. Union), 469-584.

von der Borch, C. C., Sclater, J. G., et al., 1974. Init. Repts. DSDP, 22: Washington (U.S. Govt. Printing Office).

Watts, A. B., 1988. Gravity anomalies, crustal structure and flexure of the lithosphere at the Baltimore Canyon Trough. Earth Planet. Sci. Lett., 89:221-238.

Watts, A. B., Bodine, J. H., and Steckler, M. S., 1980. Observations of flexure and the state of stress in the oceanic lithosphere. J. Geophys. Res., 85:6369-6376.

Weis, D., Beaux, J. F., Gautier, I., Giret, A., and Vidal, P., 1987. Kerguelen Archipelago: geochemical evidence for recycled material. Nato ASI Workshop, Abst., May 25-29, Antalaya, Turkey, 122-125.

Weissel, J. K., and Karner, G.D., in press. Flexural uplift of rift flanks due to mechanical unloading of the lithosphere during extension. $J$. Geophys. Res.

Wiens, D. A., Demets, C. A., Gordon, R. G., Stein, S., Argus, D., Engeln, J. F., Lundgren, P., Quible, D., Stein, C., Weinstein, S., and Woods, D. F., 1985. A diffuse plate boundary model for Indian Ocean tectonics. Geophys. Res. Lett., 12:429-432.

Wise, W. S., 1982. A volume-time framework for the evolution of Mauna Kea volcano, Hawaii. EOS, Trans. Am. Geophys. Union., 63:1137. (Abstract)

Wyrtki, K., 1973. Physical oceanography of the Indian Ocean. In Zeitschel, B. (Ed.), The Biology of the Indian Ocean: New York (SpringerVerlag), $18-36$.

\section{Ms 121A-101}

\section{APPENDIX}

\section{Plate Reconstructions for the Eastern Indian Ocean}

This Appendix contains maps of the eastern Indian Ocean for various times that are relevant for studies of the sites drilled during ODP Leg 121. These plate reconstructions were produced using a proprietary computer program developed by the Paleoceanographic Mapping Project at the Institute for Geophysics, University of Texas at Austin (UTIG). The maps were produced aboard ship by Jerry Newman with a Macintosh SE computer, provided courtesy of Dr. John Sclater. The plate model was developed by several people at UTIG, and this particular model is discussed fully by Royer et al. (in press). All reconstructions assume that Antarctica is the fixed reference frame. 


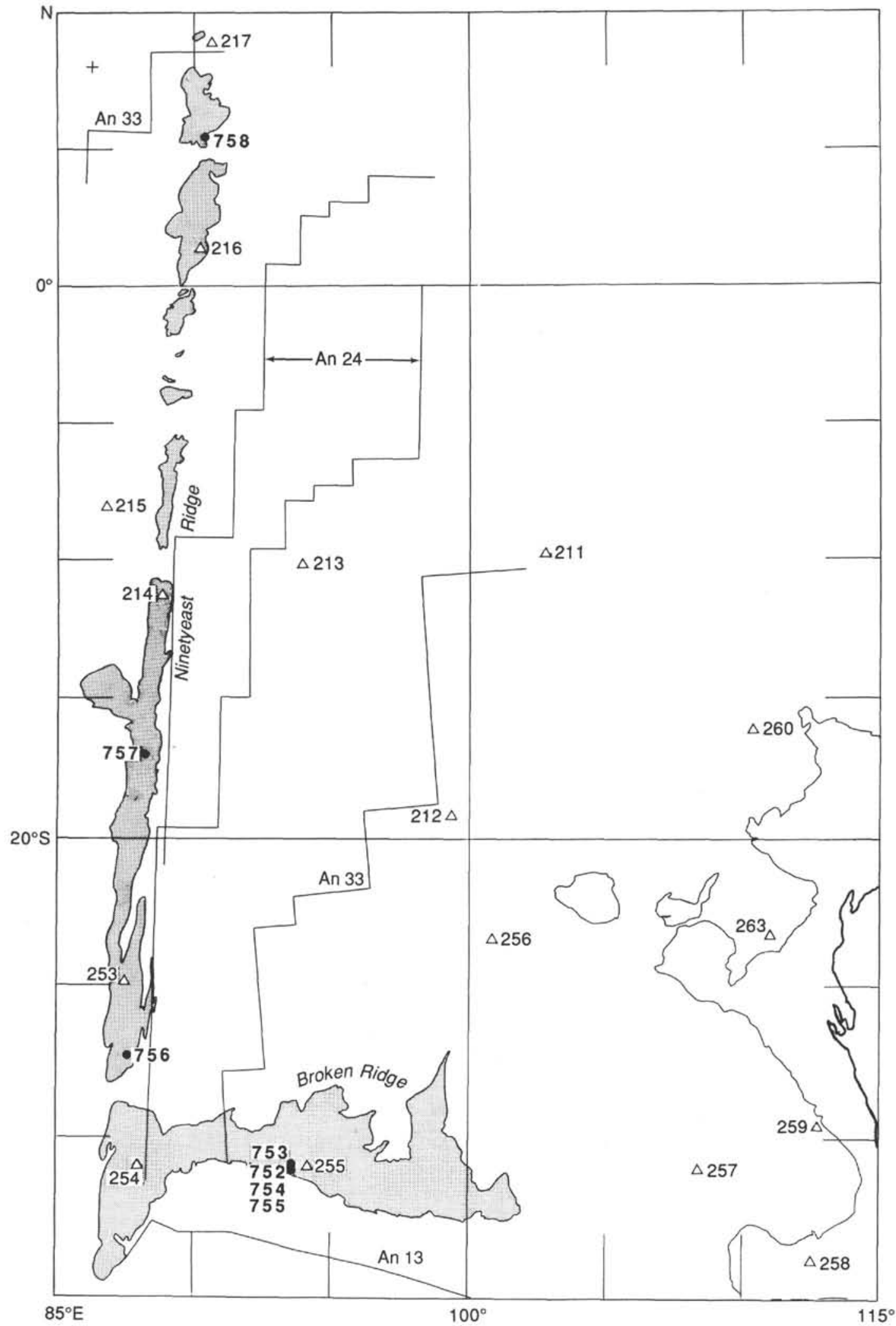

Figure 1. Major features of the subtropical eastern Indian Ocean. Heavy line denotes the Australian shoreline. The 4000-m isobath outlines the Australian continental margin; the 3000-m isobath outlines Ninetyeast and Broken ridges. DSDP and ODP drill sites are labeled. Mapped and presumed positions of seafloor magnetic anomalies 13 ( $35.5 \mathrm{Ma})$, 24 (56.1 Ma), and $33(80.2 \mathrm{Ma})$ are shown. 
LEG 121 BACKGROUND AND OBJECTIVES

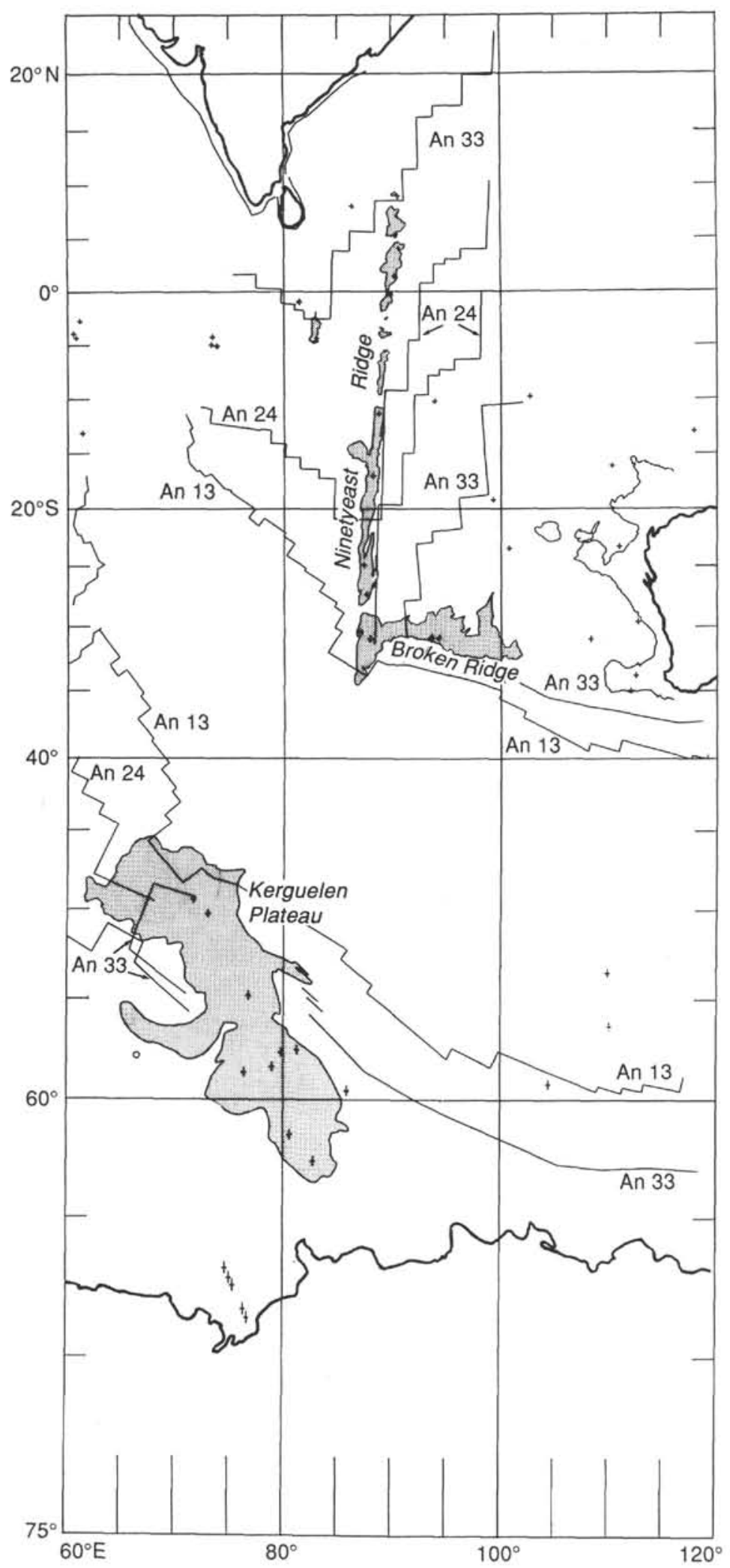

Figure 2. Map of the eastern Indian Ocean. Continental shorelines of India, Australia, and Antarctica are shown as heavy lines. The 4000-m isobath outlines the continental margins of Australia and India; the $3000-\mathrm{m}$ isobath outlines the major ridges and plateaus (shaded): Ninetyeast Ridge, Broken Ridge, and Kerguelen Plateau. Locations, both mapped and presumed, of seafloor magnetic anomalies 13 (35.5 Ma), 24 (56.1 Ma), and 33 (80.2 Ma) are shown. Small crosses are locations of DSDP and ODP drill sites (see Fig. 3).

25 


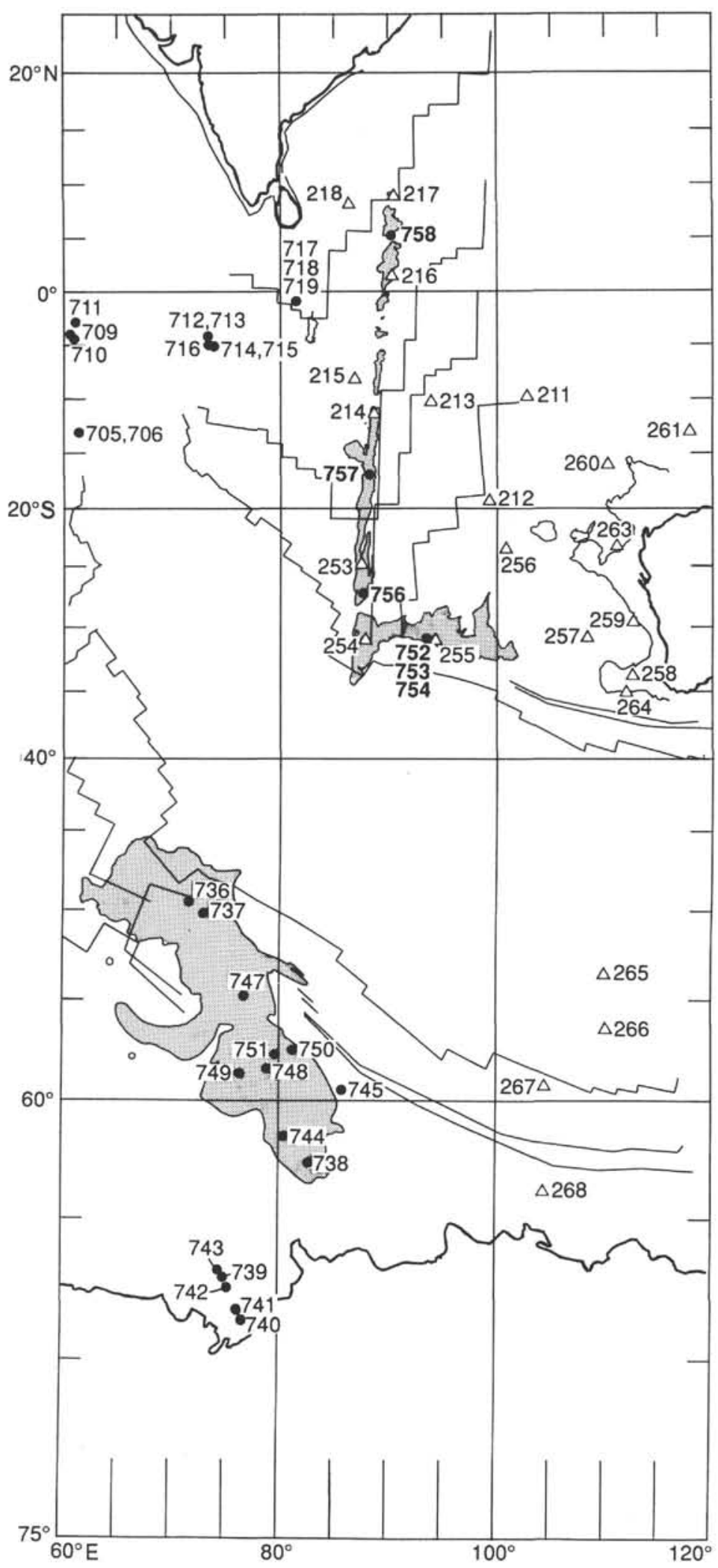

Figure 3. Map of the eastern Indian Ocean showing locations of DSDP (open triangles) and ODP (dots) drill sites through Leg 121. 


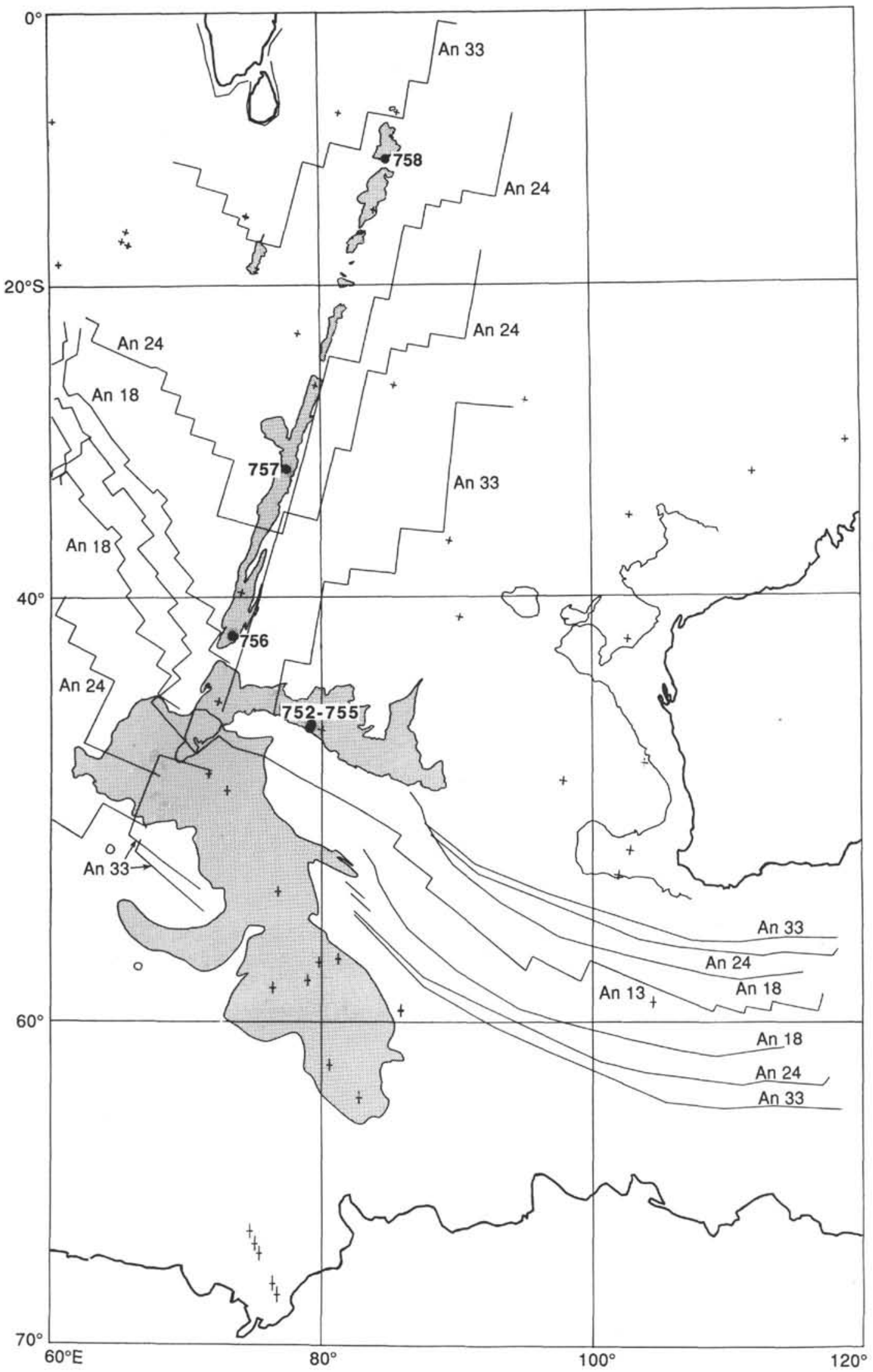

Figure 4. Major features of the eastern Indian Ocean at the time of anomaly 13, 35.5 Ma. Physiography as on Appendix Figure 2; subsidence is not taken into account. DSDP and ODP drill sites are as shown on Appendix Figure 3; Leg 121 drill sites are labeled. Mapped and presumed locations of anomalies 13, 18 (42.7 Ma), 24 (56.1 Ma), and 33 (80.2 Ma) are shown. 


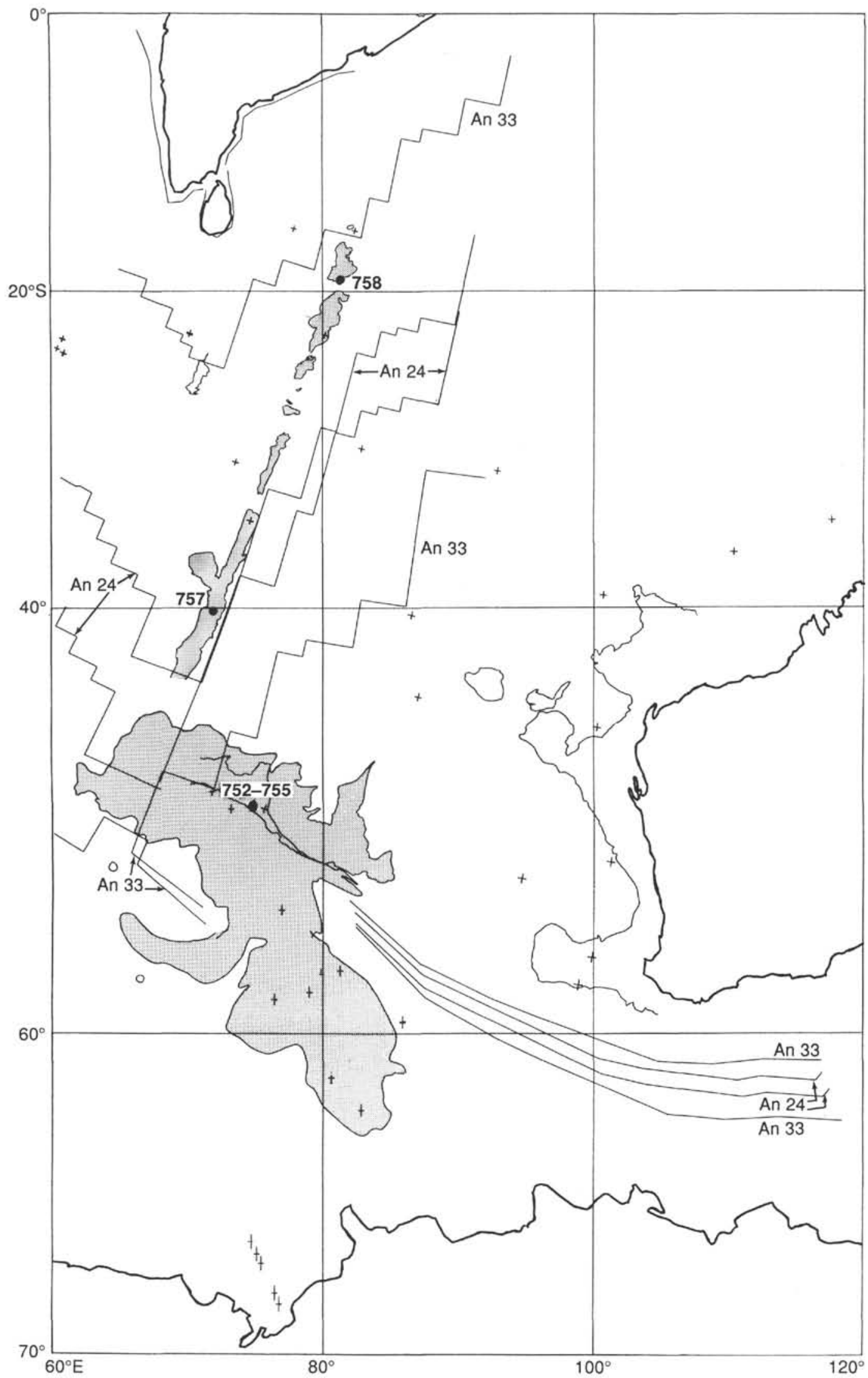

Figure 5. Major features of the eastern Indian Ocean at the time of anomaly 21, 50.3 Ma. Physiography as on Appendix Figure 2; subsidence is not taken into account. DSDP and ODP drill sites are as shown on Appendix Figure 3; Leg 121 drill sites are labeled. Mapped and presumed locations of anomalies 24 (56.1 Ma) and 33 (80.2 Ma) are shown. 


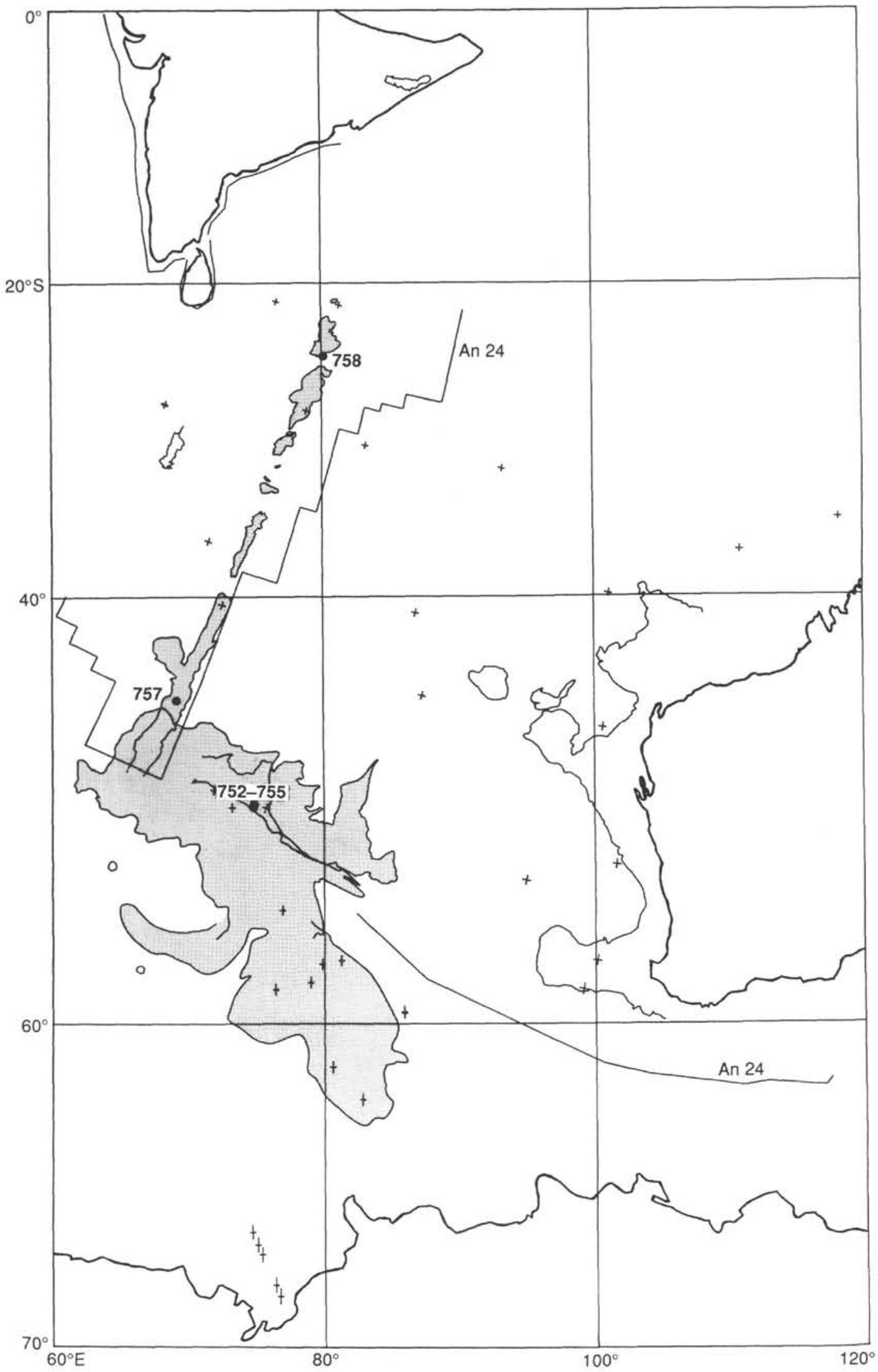

Figure 6. Major features of the eastern Indian Ocean at the time of anomaly 24, 56.1 Ma. Physiography as on Appendix Figure 2; subsidence is not taken into account. DSDP and ODP drill sites are as shown on Appendix Figure 3; Leg 121 drill sites are labeled. Mapped and presumed locations of anomaly 24 are shown. 


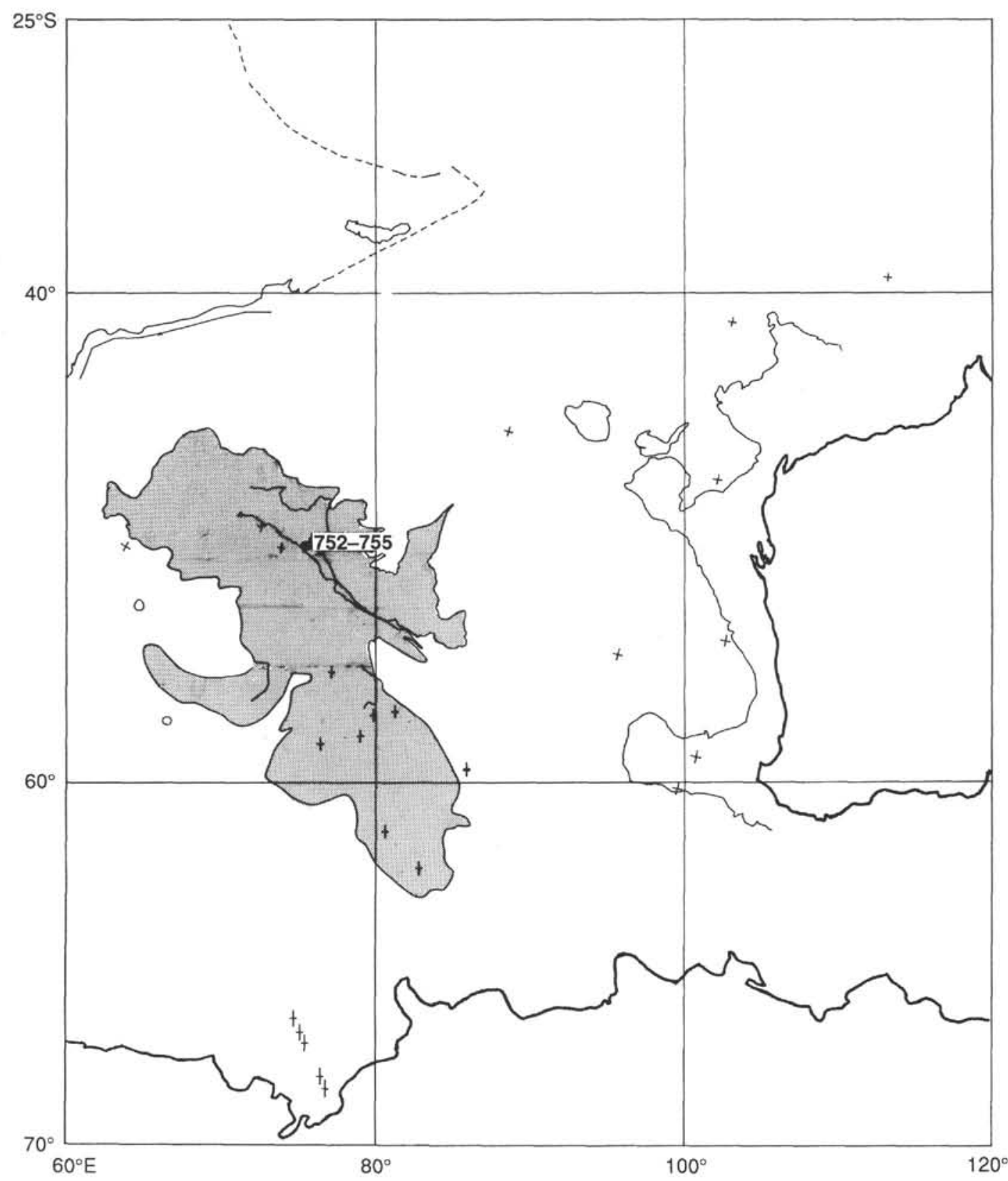

Figure 7. Major features of the proto-Indian Ocean at the time of anomaly $34,84 \mathrm{Ma}$. Physiography as on Appendix Figure 2; subsidence is not taken into account. DSDP and ODP drill sites are as shown on Appendix Figure 3; Leg 121 drill sites are labeled. The Indian subcontinent is present upper left, Kerguelen Plateau at center left, and Antarctica at the bottom of the figure. 


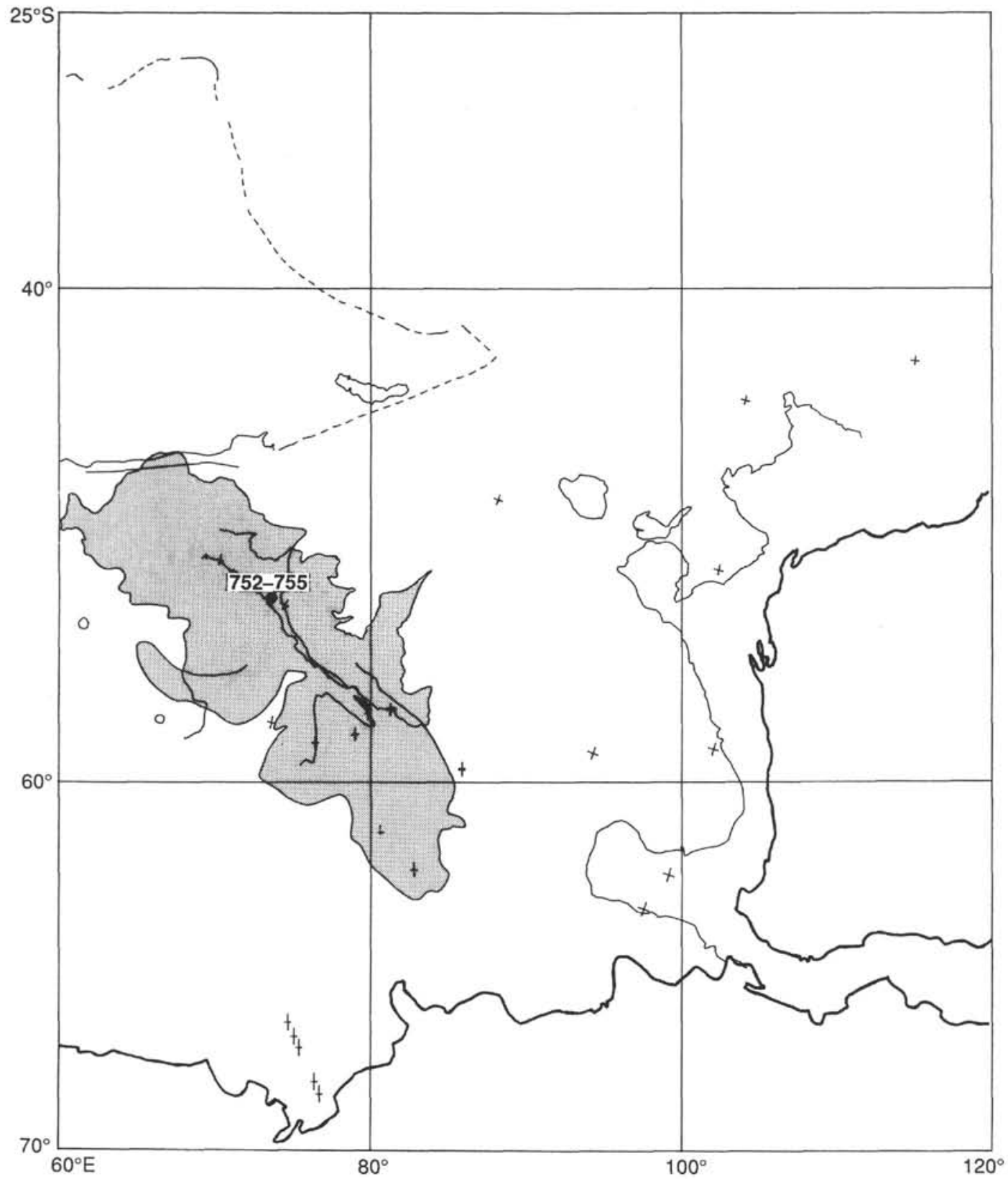

Figure 8. Major features of the proto-Indian Ocean at $95 \mathrm{Ma}$. Physiography as on Appendix Figure 2; subsidence is not taken into account. DSDP and ODP drill sites are as shown on Appendix Figure 3; Leg 121 drill sites are labeled. Continents and plateaus as shown on Appendix Figure 7. 